\title{
An integrative assessment of environmental degradation of Caveira abandoned mine area (Southern Portugal)
}

\author{
E. Ferreira da Silva ${ }^{\text {a,* }}$, N. Durães ${ }^{\text {a }}$, P. Reis ${ }^{\text {a }}$, C. Patinha ${ }^{\text {a }}$, J. Matos ${ }^{\text {b }}$, M.R. Costa ${ }^{\text {c }}$ \\ a Universidade de Aveiro, Departamento de Geociências, GeoBioTec - Geobiociências, Geotecnologias e Geoengenharia Research Centre, Campus de Santiago, 3810-193 Aveiro, Portugal \\ ${ }^{\mathrm{b}}$ LNEG Beja. Rua Frei Amador Arrais Nº 39 r/c, Apartado 104. 7801-902 Beja CODEX Beja Portugal \\ c Universidade de Trás-os-Montes e Alto Douro, Departamento de Geologia, Apartado 1013, Quinta de Prados, 5001-801 Vila Real, Portugal
}

\section{A R T I C L E I N F O}

\section{Article history:}

Received 16 March 2015

Revised 26 July 2015

Accepted 6 August 2015

Available online $\mathrm{xxxx}$

\section{Keywords:}

Trace metal pollution

Acid mine drainage

Environmental impact

Iberian Pyrite Belt

\begin{abstract}
A B S T R A C T
Since the end of the 1990s the Portuguese Iberian Pyrite Belt (IPB) is a typical European post-mining region with significant problems related to acid mine drainage (AMD), metal dispersion, mine waste management and unsafe mining infra-structures. The Portuguese government is providing particular attention on the sulphide abandoned mines and doing considerable investments on the mining recovery all over the country.

The former Caveira mine was closed in the 1980s. It is considered an extremely impacted site due to the dimension of the areas affected by mining activities. Tailings, mine addicts and associated waste rock dumps, resulting from 129 years of pyrite and Cu exploitation, are spread along the Grândola stream. Despite the semi-arid climatic conditions of the area, the tailings are considerably eroded by the surficial waters, particularly during rainfall events. The past mining and smelting activities have resulted in severe contamination of the Grândola stream and its tributary by AMD $(\mathrm{pH}<2)$ as well as degradation of surrounding stream sediments, soils and vegetation. In order to evaluate possible environmental risks, a sediment and surface water survey was carried out downstream the Caveira mine. The acidic effluent and mixed stream water show high $\mathrm{Al}, \mathrm{As}, \mathrm{Ca}, \mathrm{Cd}, \mathrm{Cu}, \mathrm{Fe}, \mathrm{Hg}, \mathrm{Mg}, \mathrm{Mn}, \mathrm{Ni}, \mathrm{Pb}$ and $\mathrm{SO}_{4}$ concentrations, with several of these contaminants exceeding local and/or surface water quality standards. The data show a strong seasonal variation of surface water quality with poorer water quality during the dry and rainy seasons caused by evaporation and efflorescent salt dissolution, respectively. The variable flow regime at the local streams causes dilution of AMD rich in trace metals reaching background within $14 \mathrm{~km}$ downstream. The potential toxicity of stream metal concentrations was determined using cumulative criterion unit (CCU) scores and the modified AMD index (MAMDI), which highlighted $\mathrm{As}, \mathrm{Cd}, \mathrm{Cu}, \mathrm{Pb}$ and $\mathrm{Zn}$ as the major sources of potential chronic stream toxicity, with emphasis on winter season. Although the threshold of the likely harm to aquatic life is exceeded at all sites, the two indexes highlight differences relating to the extension of contamination effects. The Average Index of Toxicity (AIT) showed that sediment contamination is very high even when the distance to mine promoted a decreasing in water metal concentrations, which are being precipitated in the sediments due to $\mathrm{pH}$ increase.
\end{abstract}

(c) 2015 Elsevier B.V. All rights reserved.

\section{Introduction}

The Iberian Pyrite Belt (IPB) is known as a mining district of worldwide significance, due to the unusual metal sulphide concentration of its large and medium sized mineral deposits. Mining activity in this district dates back to the Roman times and was an important sector of the Portuguese economy during the 19th and the first half of the 20th centuries. The majority of the mining activity ceased due to the ore exhaustion and to the introduction of new and more profitable techniques elsewhere, reducing the ore prices, which made the extraction of these mines unviable (Martins and Oliveira, 2000).

\footnotetext{
* Corresponding author.

E-mail address: eafsilva@ua.pt (E. Ferreira da Silva).
}

Sulphide ore mines produce huge amounts of waste material that is often rich in pyrite and other sulphides. The exposure of these sulphurbearing minerals to the air and water promotes their oxidation and hydrolysis leading to sulphuric acid production, which is enhanced by the high reactive surface promoted by the mill processes. This situation is worsened due to the mine abandonment, associated with a lack of maintenance of tailings and waste dumps. In some cases, the occurrence of tailing impoundment disruptions has caused the discharge of potential harmful materials and the consequent contamination of soils and waters.

Pyrite, one of most abundant sulphide minerals, may be oxidised by biotic and abiotic processes. Sulphate, $\mathrm{Fe}$ and $\mathrm{H}^{+}$are released into solution forming what is commonly known as acid mine drainage (AMD) (Bigham and Nordstrom, 2000; Jönsson et al., 2006). The 
oxidation reaction process of pyrite can be generalized by the following equations:

$\mathrm{FeS}_{2(\mathrm{~s})}+\frac{7}{2} \mathrm{O}_{2(\mathrm{aq})}+\mathrm{H}_{2} \mathrm{O} \rightarrow \mathrm{Fe}^{2+}+2 \mathrm{SO}_{4}^{2-}+2 \mathrm{H}^{+}$

$\mathrm{Fe}^{2+}+\frac{1}{4} \mathrm{O}_{2(\mathrm{aq})}+\mathrm{H}^{+} \rightarrow \mathrm{Fe}^{3+}+\frac{1}{2} \mathrm{H}_{2} \mathrm{O}$

$\mathrm{Fe}^{3+}+3 \mathrm{H}_{2} \mathrm{O} \rightarrow \mathrm{Fe}(\mathrm{OH})_{3(\mathrm{~s})}+3 \mathrm{H}^{+}$

$\mathrm{FeS}_{2(\mathrm{~s})}+14 \mathrm{Fe}^{3+}+8 \mathrm{H}_{2} \mathrm{O} \rightarrow 15 \mathrm{Fe}^{2+}+2 \mathrm{SO}_{4}^{2-}+16 \mathrm{H}^{+}$.

By Eq. (1), pyrite is oxidized, thereby releasing $\mathrm{Fe}^{2+}, \mathrm{SO}_{4}^{2-}$ and $\mathrm{H}^{+}$. Ferrous iron can be oxidized to $\mathrm{Fe}^{3+}$ in an acid consuming reaction (Eq. (2)). The low rate of this reaction in acidic conditions is overcome by the occurrence of acidophilic bacteria that greatly enhances the $\mathrm{Fe}^{2+}$ oxidation (Singer and Stumm, 1970). Ferric iron can then either be hydrolysed and form ferric hydroxide $\left[\mathrm{Fe}(\mathrm{OH})_{3}\right]$ and $\mathrm{H}^{+}$(Eq. (3)), or it can directly oxidize pyrite, acting as a catalyst, leading to the generation of $\mathrm{Fe}^{2+}$ and $\mathrm{SO}_{4}^{2-}$, and high acidity ( 8 times higher than oxidation of pyrite by $\mathrm{O}_{2}$ ) (Eq. (4)). Actually, $\mathrm{Fe}^{3+}$ is the only effective oxidizer of pyrite in acidic conditions (Singer and Stumm, 1970). The ferric hydroxides, formed by $\mathrm{Fe}^{3+}$ hydrolysis, precipitate as ochre coatings on stream beds affected by AMD and can also coat the pyrite surface preventing its oxidation. Thus, the AMD extent impact on the stream waters may depend on the pyrite content and its oxidation rate (Kim et al., 2003).

AMD has environmentally significant consequences by the high acidity, the leaching of toxic metals from wastes and their spread in the environment, affecting the delicate and highly vulnerable aquatic systems (Chapman et al., 1983; Herr and Gray, 1996; Protano and Riccobono, 2002). The AMD with high concentration of $\mathrm{SO}_{4}, \mathrm{Fe}, \mathrm{Al}$ and Mn shows pH values near 2 or lower (Chon et al., 1999; Nordstrom et al., 2000). From an ecotoxicological point of view, greater attention has traditionally been paid to hazardous elements such as $\mathrm{As}, \mathrm{Cd}, \mathrm{Cu}$, $\mathrm{Hg}$ and $\mathrm{Pb}$, whose adverse effects on life are well established. The dissolved species of these elements may precipitate in the stream bottom under control of the chemical conditions from streams.

This study was intended to investigate and quantify the disturbances that occur in the surrounding environment of the abandoned sulphide mine of Caveira, on the basis of geochemical content and behaviour in the stream sediments and surface waters as the main receptors. In addition, the impacts of trace elements and AMD in biota were estimated. Considering that mining environmental impacts are site specific, the characterization and the understanding of these local contamination processes are crucial in the definition of an environmental remediation plan of the mining area.

\section{Study area}

\subsection{Geographical and geomorphological setting}

The Caveira mine is located in the NW extreme limit of the IPB, in the south of Portugal (Alentejo), and belongs to the Grândola municipality (Fig. 1). This is an abandoned sulphide mine, where mining focused mainly in the pyrite exploitation for sulphuric acid production. The degradation of the old mining quarters and the non-natural hill formed by the tailing deposits cause a striking visual impact in the landscape.

The geomorphology of the region is characterized by smooth reliefs, strongly controlled by the WNW-ESE major Grândola active fault. Close to the main streams the relief is moderate with slopes ranging from to 2 to $5 \%$, whereas the neighbouring hills are dominated by long steep slopes (10\%-35\%) and intensely forested with eucalyptus. Since the mine closure, human occupation is very limited, where cereal agriculture (only in the northern sector) and forest are the main local land use.

The watercourses in the vicinity of the mining area belong to the Sado watershed, which shows a median slope of about $4 \%$. The main watercourse of the region is the Sado river, with a length of $176 \mathrm{~km}$ and a medium flow rate of $8.7 \mathrm{~m}^{3} \cdot \mathrm{s}^{-1}$ (highly variable between summer and winter) (source: SNIRH-APA). Another important watercourse in this site is the Grândola stream that like other small streams in the region is temporary, with a medium flow rate of $1.44 \mathrm{~m}^{3} \cdot \mathrm{s}^{-1}$, ranging from 0 to $123 \mathrm{~m}^{3} \cdot \mathrm{s}^{-1}$ among driest and wettest periods, respectively (source: STREAMES). This situation may cause the fragmentation of channel during summer into a series of isolated pools (Morais et al., 2004).

\subsection{Geology and mineralization}

The geological sequence at Caveira is represented from bottom to top by phyllites and quartzites (PQG), follow by a volcanic sedimentary complex sequence (VSC) unit (Late Famennian-Late Visean) represented by dark grey and siliceous shales and rare jaspers (Fig. 1). In the northern sector late intrusive diabase rocks are identified. The Caveira antiform contacts south-westward, by a major thrust, with the flysch Mértola Formation (Upper Visean).

The Caveira structure is controlled by N-S and NE-SW late-variscan faults and the polymetallic massive sulphide mineralization is located along a structural lineament of the VSC (Fig. 1), where the Volcanic Hosted Massive Sulphide (VHMS) type deposits are found (Oliveira et al., 2001).

The mineralization is distributed by several small massive sulphide orebodies: Salvador, António, Frederico, Pero-Cuco and Canal, with 22-65 m length dimension and 1.5-7 m thick. Two mineralised horizons are present in the western and eastern sectors of the Caveira N-S geological antiform structure, namely: Helena shaft sector hosting the Salvador-Esperança and NW-S João orebodies; and Luísa shaft sector hosting the Canal-Frederico-Francisco and Augusto-António orebodies (Castelo Branco, 1994; Matos et al., 2003a). Canal, António and Frederico orebodies are associated with black shales and felsic volcanic rocks (Matos, 2006) and located near de VSC/PQG (Late Strunian) contact (Fig. 1).

The mineralization of the Caveira is similar to that from Lousal (Matos and Oliveira, 2003; Strauss, 1970) and is dominated by pyrite $\left(\mathrm{FeS}_{2}\right)$, with variable amounts of chalcopyrite $\left(\mathrm{CuFeS}_{2}\right)$, galena $(\mathrm{PbS})$ and sphalerite $(\mathrm{ZnS})$. Other accessory minerals are pyrrhotite $(\mathrm{FeS})$, marcasite $\left(\mathrm{FeS}_{2}\right)$, bournonite $\left(\mathrm{CuPbSbS}_{2}\right)$, tetrahedrite $\left[\left(\mathrm{Cu}_{2} \mathrm{Ag}_{2} \mathrm{FeZnHg}\right)_{3}(\mathrm{SbAs})_{2} \mathrm{~S}_{6}\right]$, arsenopyrite (FeAsS), cobaltite (CoAsS), goethite ( $\mathrm{FeOOH})$, magnetite $\left(\mathrm{Fe}_{2} \mathrm{O}_{4}\right)$, and native gold (Au) (Matzke, 1971; Strauss, 1970). At the surface the sulphide mineralization is represented by narrow gossans and associated supergene kaolin alteration (Matos et al., 2003a), mainly in the western sector of the mine (Salvador orebody - Helena shaft). The gossans are represented by massive to banded hematite, locally with limonite and minor amounts of jarosite, hosting locally important grades of precious metals, namely $\mathrm{Au}$ ( $4.5 \mathrm{mg} \mathrm{kg}^{-1}$ ) and $\mathrm{Ag}$ $\left(45-300 \mathrm{mg} \mathrm{kg}^{-1}\right.$ ). The grade of $\mathrm{Cu}$ is $<10 \%$ and $\mathrm{S} 3-6 \%$ (SIORMINP, 2002).

\subsection{Mining activity and environmental issues}

The Caveira mine has a long exploitation history that started in the Roman period. A large number of shafts, galleries and in situ tailings (>2 Mt - Matos et al., 2003a) are presented in the mining area (Fig. 1). The gossan and supergene zones of the two main horizons (Helena and Luísa shafts) were intensely mined between 1864 and 1886. The XIX century mine exploitation was conditioned by the site location (very isolated at that time) and by a great underground fire (1880 to 1882), related with pyrite spontaneous combustion (Matos and Martins, 2006). The mining activities took place until 1919, during the period between 1936 and 1943 and from 1952 to 1958.

The mining activity was responsible by significant downstream contamination (Cardoso Fonseca and Ferreira da Silva, 2000; Matos and Martins, 2006). The mine is characterized by the main tailing (approximately $2 \mathrm{Mt}$ ), two small acid water dams, several ruins of the 


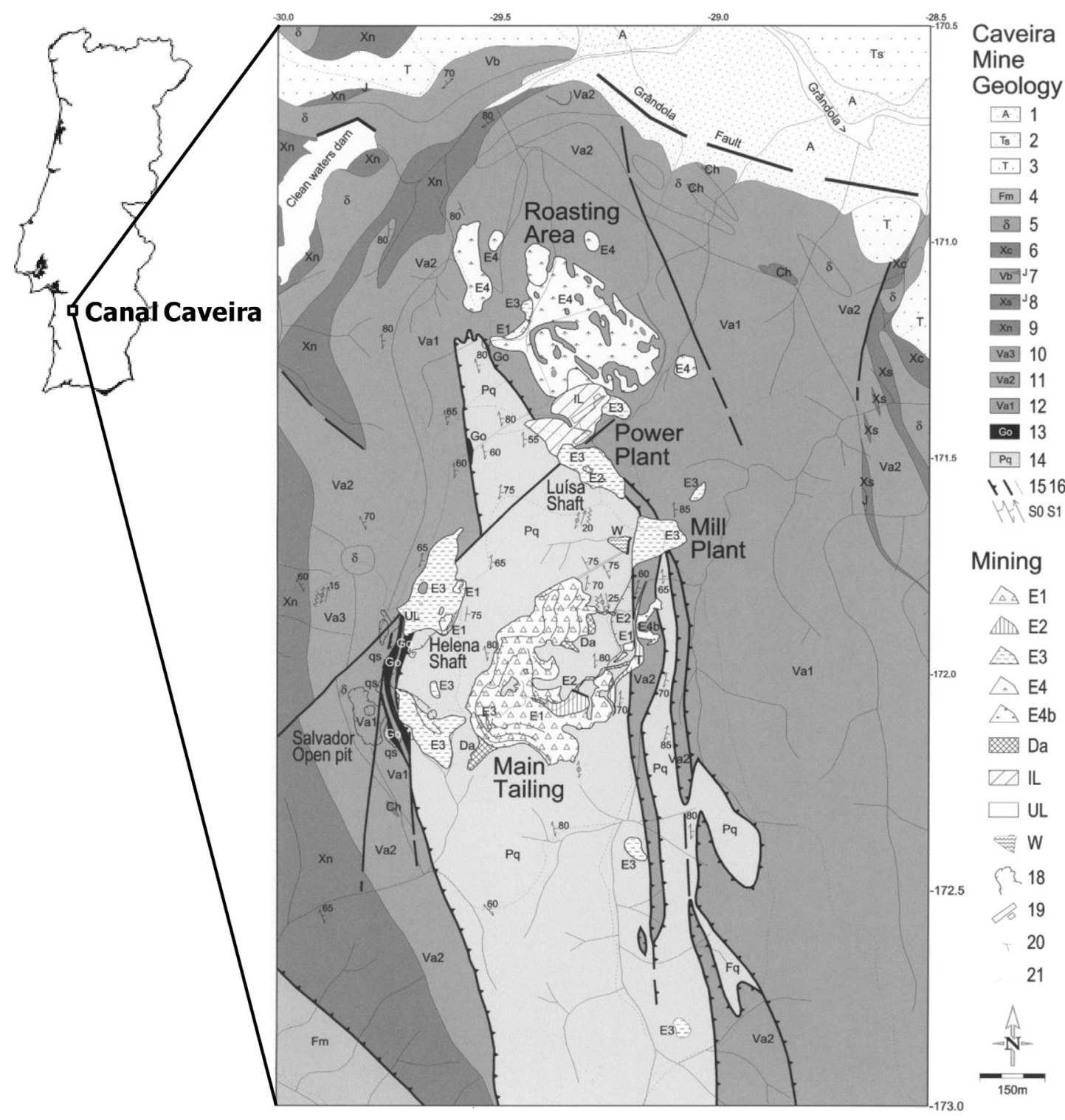

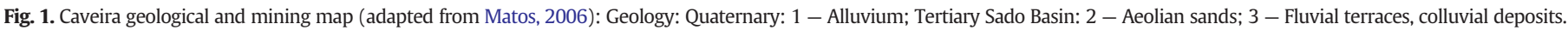

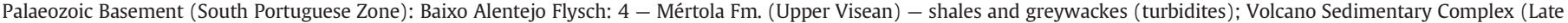

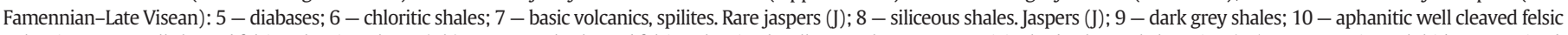

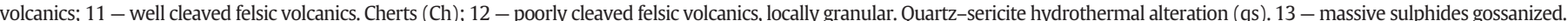

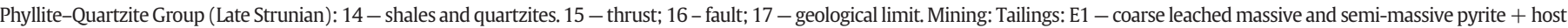

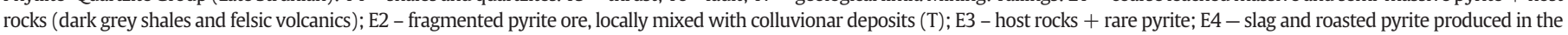

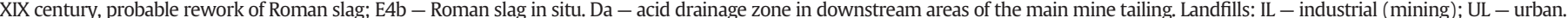
Other: W - acid water dam; 18 - open pit/strong slope; 19 - mining building; 20 - stream; 21 - road/track. Hayford-Gauss coordinates indicated in km.

miner's quarters, a power plant, a mill plant and the roasting area (Fig. 1). The main tailing is situated on the top of the Caveira central hill, in unstable slope conditions, showing intense rill and gully erosion, and causing an important visual impact in the landscape. The mine wastes cover an area of approximately $217,103 \mathrm{~m}^{2}$ (Table 1 ) and these materials (composed of ore host rocks and sulphides) were dispersed in the high slope hills to facilitate the leaching process of the poor ore metal content. The liquors generated were then collected in a tank where copper cementation took place (Matos and Martins, 2006; Matos et al., 2008a, 2008b).

Fieldwork carried out at Caveira mine revealed: (a) uncovered slopes due basically to the forest fires; (b) strong erosion of unprotected tailings; (c) large areas of gangue and extensive tailing deposits; (d) the easily circulation and percolation of rainwater over and through tailing materials, causing significant erosion and transport of tailings debris to areas nearby and downstream; (e) the damaged and insecurity of the dam constructed to avoid the AMD and the mechanical transport of tailing materials into the Grândola stream, where the wall was breached with explosives by the locals that use the accumulated water in the dam to prevent skin diseases like psoriases (the degradation of this structure has been increased by the erosion); (f) the use of the mining slag in road pavement, reported since the $60 \mathrm{~s}$, which strongly contributes to the contamination dispersion; (g) very dangerous open pits, shafts and ruins; and (h) the presence of old mining infrastructures, such as the power plant and the mill plant, the roasting area, and a small acid water dam (Fig. 1).

The degradation of mine facilities causes the uncontrolled movement of waste material and contaminated water from the mine area. Thus, the sediments located downstream and close to the tailings show a black tinge due to the inputs of eroded tailings, whilst the stream water shows frequently a reddish colour related with AMD processes. 
Table 1

Caveira mining site description: waste volumes and typology; landfill occupation; and the extension of the affected areas.

Adapted from Matos, 2006.

\begin{tabular}{|c|c|c|c|c|}
\hline Caveira mine - waste class & Area $\left(\mathrm{m}^{2}\right)$ & $\%$ & Volume $\left(\mathrm{m}^{3}\right)$ & $\%$ \\
\hline $\mathrm{E} 1$ - (py, cpy, ga, sph, apy, and minor tt) + host rocks - wastes from the sulphide ore in depth & 71,911 & 30.49 & 431,466 & 43.64 \\
\hline E2 - similar to E1 with predominance of leached materials like sulphates & 4360 & 1.85 & 13,080 & 1.32 \\
\hline E3 - host rocks + rare py - wastes from the exploitation of the gossans & 61,980 & 26.28 & 309,900 & 31.34 \\
\hline E4 - Fe silicates (olivine) + mgn + minor sulphides and also haematitic crusts linked to roasting method & 76,620 & 32.49 & 229,860 & 23.25 \\
\hline E4b - Roman slags. Significant haematitic alteration and Cu secondary minerals & 2232 & 0.95 & 4464 & 0.45 \\
\hline IL - industrial landfill & 13,661 & 5.79 & 68,305 & - \\
\hline UL - urban landfill & 594 & 0.25 & 1188 & - \\
\hline Areas affected by mine drainage (AMD) & 3256 & 1.38 & - & \\
\hline Acid water dam & 1239 & 0.53 & - & \\
\hline Total area affected by mining activity & 235,853 & 100.00 & & 100.00 \\
\hline
\end{tabular}

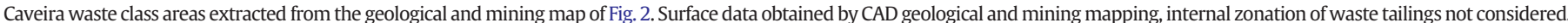

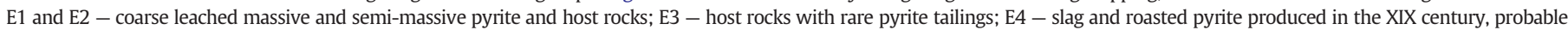

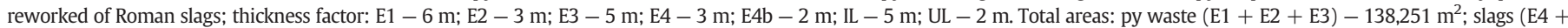

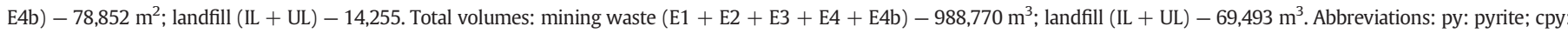
chalcopyrite; ga: galena; sph: sphalerite; apy: arsenopyrite; tt: tenantite; mgn: magnetite.

a Related to total area.

b Related to total mining waste volume.

\section{Materials and methods}

\subsection{Sampling and sample preparation}

The fieldwork included the identification and sampling of the different acid mine effluents and stream waters, as well as stream sediments. In addition, samples from the massive sulphide host rocks and tailing materials were also collected.

\subsubsection{Rock, pyrite ore and tailing waste samples}

Volcanic massive sulphide host rocks [phyllites and quartzites (PQ), quartz-feldspar porphyritic volcanics (Va1), felsic volcanics (Va2), gossan $(G)$, black shales with disseminated pyrite ore (BSPy)] and tailing waste samples (E1, E2, E3, E4, E4b) were collected from the study area.

About $1 \mathrm{~kg}$ of each rock sample was dried at $40^{\circ} \mathrm{C}$, crushed with a jaw crusher, pulverized in a mechanical agate mill and reduced to $250 \mathrm{~g}$ by

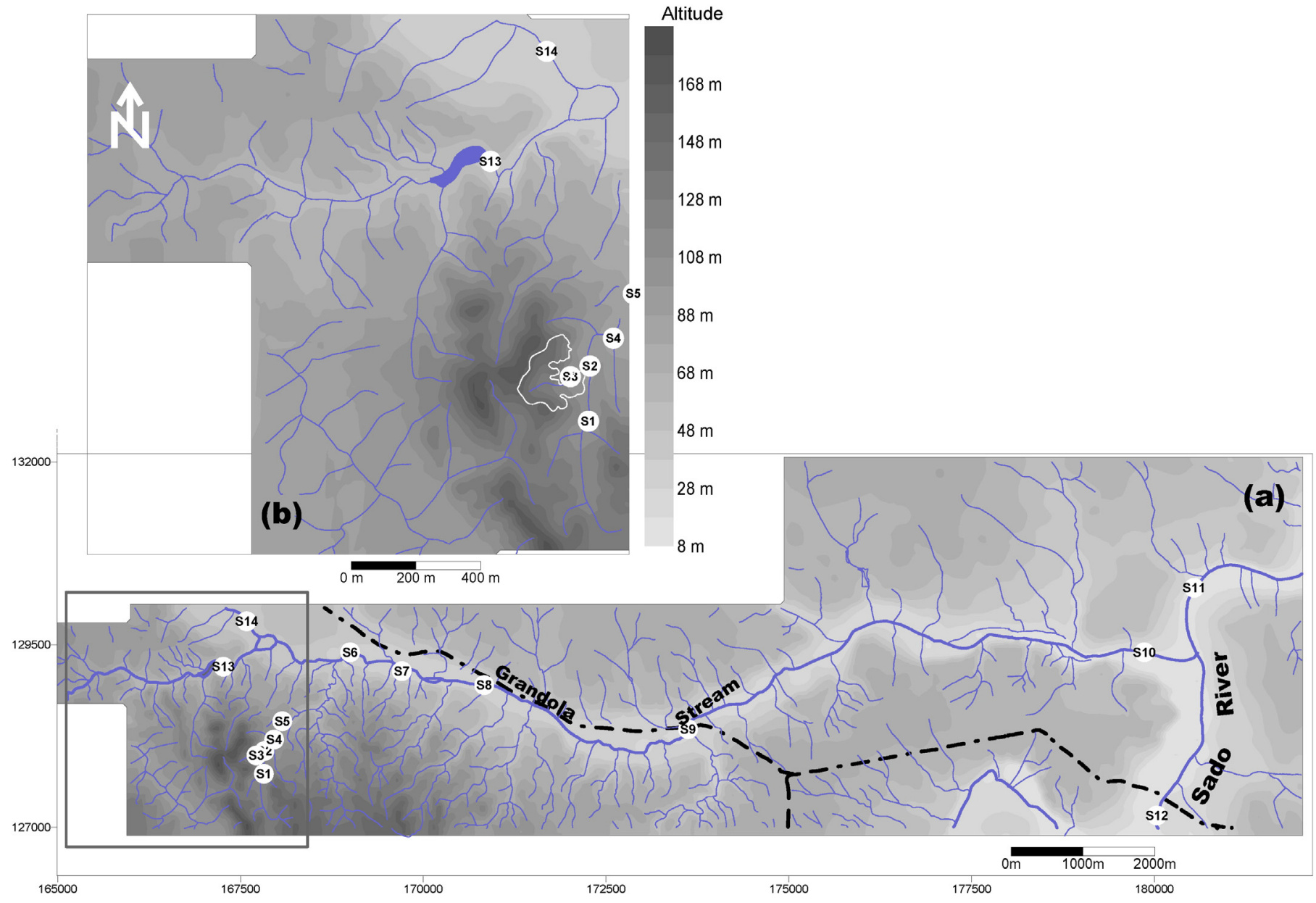

Fig. 2. Sampling map (stream sediment and water samples) of the Caveira mining area. 
coning and quartering, where aliquots of 30-50 g of each sample were separated for chemical and mineralogical analysis.

\subsubsection{Stream sediment samples}

14 samples were collected along the study area (Fig. 2) during the spring season (SPS) campaign. Samples affected by AMD were collected from Grândola stream (SS7 to SS10 and SS14) and its tributary (SS1 to SS6). Samples from unimpacted sites were collected from the upstream section of the Grândola stream (SS13) and Canal stream (SS14), representative of local geochemical background, and from Sado river (SS11 and SS12).

The samples were collected with a plastic spade, transferred to precleaned plastic bags, sealed and taken to the laboratory, where they were oven dried at $40{ }^{\circ} \mathrm{C}$, until a constant weight was attained. Then, samples were disaggregated, sieved through a $<177 \mu \mathrm{m}$ mesh aperture plastic sieve and grinded in an agate mill. This fine sediment fraction is particularly useful for estimating the relative degree of pollution and to distinguish natural (geogenic) and anthropogenic sources (Kralik, 1999). Aliquots of 30-50 g of each sample were separated for analysis through coning and quartering homogenization to get a representative subsample related to the original sample.

\subsubsection{Water samples}

Acid mine waters, stream water affected by AMD, and unpolluted stream water samples were collected during three seasonal periods: after a rainy period (winter season: WIS), during normal flow conditions (spring season: SPS), and in a dry period without or with very scarce rainfall episodes (summer season: SUS). Acid mine waters were taken from the flowing channels: water flowing from the waste piles E1 (AMW3); and from the impoundment (sample AMW4). Downstream water near the Caveira mining area and affected by AMD was collected from Grândola stream (samples SW7, SW8, SW9 and SW10) and from its tributary (SW1, SW2, SW5 and SW6) (Fig. 2). The unimpacted sampling sites were the Sado river (SW11 and SW12), the upstream section of the Grândola stream (SW13) and the Canal stream (SW14) (Fig. 2) and, where these two last samples were considered as the local geochemical background. Some of these sampling points are ephemeral, being active only after rainfall episodes.

Water samples for chemical analysis were collected with syringes and Millipore standard sampling equipment, filtered in the field through $0.45 \mu \mathrm{m}$ Millipore cellulose filters and stored in clean $250 \mathrm{~mL}$ polyethylene bottles (ASTM, 1984). Two sets of samples were collected at each site: (1) those destined for cation analysis were acidified with $35 \%$ $\mathrm{HNO}_{3}$ to $\mathrm{pH}$ less than 2.0; and (2) unacidified samples for anion analysis. Field blank preservation follows the same procedure as samples. Samples were transported in an ice box and then stored at $4{ }^{\circ} \mathrm{C}$ in a freezer prior to laboratory analyses.

\subsection{Methods}

\subsubsection{Field parameters}

Temperature ( $\mathrm{T}), \mathrm{pH}$, and electric conductivity (EC) were measured in situ at each sampling site. The $\mathrm{pH}$ was measured with a $\mathrm{HI} 8424 \mathrm{pH}$ meter from HANNA, previously calibrated (Titrisol standard solutions) at $\mathrm{pH} 4.0$ and $7.0\left(25^{\circ} \mathrm{C}\right)$. The EC was measured using a $\mathrm{HI} 8633$ multirange electric conductivity meter from HANNA, previously calibrated with a $1413 \mu \mathrm{S} \mathrm{cm}^{-1}$ standard solution $\left(25^{\circ} \mathrm{C}\right)$.

\subsubsection{Chemical analysis}

3.2.2.1. Rock, pyrite ore, tailing waste and stream sediment samples. Multielemental chemical analysis was conducted on powdered rock and sediment samples $(<177 \mu \mathrm{m})$ at ACME Labs (Anal. ISO 9002 Accredited Lab - Canada). The selected samples were fused with lithium metaborate $\left(\mathrm{LiBO}_{2}\right)$ followed by a multi-acid digestion $\left(\mathrm{HCl}-\mathrm{HF}-\mathrm{HNO}_{3}-\mathrm{HClO}_{4}\right)$ dissolution. The solutions were analysed by inductively coupled plasma emission spectrometry (ICP-ES) for major elements. For trace elements analysis ( $\mathrm{Ag}, \mathrm{Al}, \mathrm{As}, \mathrm{Bi}, \mathrm{Cd}, \mathrm{Co}, \mathrm{Cu}, \mathrm{Fe}, \mathrm{Hg}, \mathrm{Mn}, \mathrm{Mo}, \mathrm{Ni}, \mathrm{Pb}, \mathrm{Sb}$, and $\mathrm{Zn}$ ) a $0.5 \mathrm{~g}$ split was leached in hot $\left(95^{\circ} \mathrm{C}\right)$ aqua regia $\left(\mathrm{HCl}-\mathrm{HNO}_{3}-\mathrm{H}_{2} \mathrm{O}\right)$ for $1 \mathrm{~h}$, followed by a dilution to $10 \mathrm{~mL}$ with distilled water and analysed by inductively coupled plasma mass spectrometry (ICP-MS). It should be noted that an aqua regia digestion do not dissolve all minerals, particularly silicates. Although, the results obtained for metals/metalloids are considered as total concentrations, due to the fact that this acidic mixture totally decomposes sulphides, which are the major sources of these elements (Alvarez et al., 2006). The determination of total carbon (TC) and sulphur (TS) were performed in ACME Labs using a carbonsulphur analyser from LECO. The loss on ignition (LOI) was determined by weight difference after ignition at $1000{ }^{\circ} \mathrm{C}$. The detection limits for trace elements were: $0.1 \mathrm{mg} \mathrm{kg}^{-1}$ for $\mathrm{Ag} ; 0.3 \mathrm{mg} \mathrm{kg}^{-1}$ for As; $0.2 \mathrm{mg} \mathrm{kg}^{-1}$ for Bi and $\mathrm{Cd}$; $1 \mathrm{mg} \mathrm{kg}^{-1}$ for $\mathrm{Co}, \mathrm{Cu}, \mathrm{Hg}$, Mo, $\mathrm{Ni}$ and $\mathrm{Zn}$; $3 \mathrm{mg} \mathrm{kg}^{-1}$ for $\mathrm{Ba}, \mathrm{Pb}$, and $\mathrm{Sb} ; 0.01 \%$ for $\mathrm{C}$, Fe and $\mathrm{S}$. The analytical precision was determined by inserting blind duplicates to approximately $10 \%$ of the total of samples. Analytical accuracy was determined using the standard reference materials S017/CSB for major elements, DS4 and DS5 standards for trace metals. The results were within the $95 \%$ confidence limits of the recommended values for these certified materials. Overall, analytical precision was $\pm 4 \%$ for the trace metals analysed.

3.2.2.2. Water samples. Unacidified samples were analysed by ion chromatography (IC) using a Dionex 1000 i workstation to determine the $\mathrm{Cl}^{-}, \mathrm{NO}_{3}^{-}$and $\mathrm{SO}_{4}^{2-}$ concentrations. An isocratic elution with a sodium bicarbonate-sodium carbonate solution was employed together with a Dionex AS4-SC column. The $\mathrm{HCO}_{3}^{-}$concentration was determined in situ by volumetric titration with sulphuric acid on filtered unacidified samples. The concentrations of major cations ( $\mathrm{Ca}, \mathrm{K}, \mathrm{Mg}$ and $\mathrm{Na}$ ) and trace elements ( $\mathrm{Ag}, \mathrm{Al}, \mathrm{As}, \mathrm{Bi}, \mathrm{Cd}, \mathrm{Co}, \mathrm{Cu}, \mathrm{Fe}, \mathrm{Hg}, \mathrm{Mn}, \mathrm{Mo}$, $\mathrm{Ni}, \mathrm{Pb}, \mathrm{Sb}$, and $\mathrm{Zn}$ ) in acidified samples were determined by ICP-MS at ACME Labs. Rigorous water data quality control was conducted by inserting reagent blanks, duplicate samples and standard reference materials (WASTWATER3) into each batch to check the validity and reproducibility of the results (Ramsey et al., 1987). Typical uncertainties including error sources were $<6 \%$ for all the trace elements, whereas for major anions, the uncertainties lie between $2 \%$ and $7 \%$, depending to the concentration levels. The detection limits for major anions and cations ( $\mathrm{Ca}, \mathrm{Cl}, \mathrm{K}, \mathrm{Mg}, \mathrm{Na}, \mathrm{NO}_{3}$ and $\mathrm{SO}_{4}$ ) determinations was less than $1 \mathrm{mg} \mathrm{L}^{-1}$, whilst the detection limits for trace elements were: $0.02 \mu \mathrm{g} \mathrm{L}^{-1}$ for $\mathrm{Co}$; $0.05 \mu \mathrm{g} \mathrm{L}^{-1}$ for $\mathrm{Ag}, \mathrm{Bi}, \mathrm{Cd}$ and $\mathrm{Sb} ; 0.1 \mu \mathrm{g} \mathrm{L}{ }^{-1}$ for $\mathrm{Cu}, \mathrm{Hg}$, Mo and $\mathrm{Pb}$; $1 \mu \mathrm{g} \mathrm{L}^{-1}$ for $\mathrm{Al}$; $0.2 \mu \mathrm{g} \mathrm{L}^{-1}$ for $\mathrm{Ni}$; $0.5 \mu \mathrm{g} \mathrm{L}^{-1}$ for As and $\mathrm{Zn}$; and $10 \mu \mathrm{g} \mathrm{L}{ }^{-1}$ for Fe.

\subsection{Data analysis}

\subsubsection{Stream sediment data}

According to Di Toro et al. (1990), stream sediment data provide a useful screening tool for identifying areas that may warrant more costly and time-consuming toxicological field studies. MacDonald et al. (2000) proposed consensus-based stream sediment quality guidelines for 28 metals and organic compounds for freshwater ecosystems. Two consensus-based values are reported for each potential contaminant: (1) the threshold effect concentration (TEC) is the concentration below which harmful effects are unlikely to be observed; and (2) the probable effect concentration (PEC) is the concentration above which harmful effects are likely to be observed. These guidelines can be applied not only for individual contaminants, but also to sets of several metals and compounds to estimate their combined toxic effects. The individual PEC quotient (PEC-Q), calculated by the chemical concentration of sediments in study site divided by the PEC SQG (sediment quality guidelines) chemical concentration, allows to infer about the expected adverse effects on benthic organisms (according to the consensusbased sediment quality guidelines), where the toxicity level increases from level 1 to 4 . 
In the case of metals, a mean PEC-Q (mPEC-Q) was calculated based on the PEC-Q summing of individual metals and dividing by the number of metals. The Average Index of Toxicity (AIT) values was estimated according the formula AIT $=101.48\left(1-0.36^{\mathrm{mPEC}-\mathrm{Q}}\right)$, which allows to estimate the probability of observing sediment toxicity (MacDonald et al., 2000).

\subsubsection{Stream water data}

Polluted mining sites are likely to contain a mixture of metals which in turn might have additive effects reaching chronic concentration. Work carried out by several authors leading to the definition of the cumulative criterion unit (CCU - Clements et al., 2000), based on total metal concentration and toxicity measurements. The CCU is calculated for any site, based on the U.S. Environmental Protection Agency toxicity thresholds (USEPA, 1986) according to the following formula:

$\mathrm{CCU}=\sum \frac{m_{i}}{c_{i}}$

where $m_{i}$ is the total recoverable metal concentration and $c_{i}$ is the criterion value for the $i$ th element. This criterion has been already applied to analyse the response of different organisms to metals in streams (Clements et al., 2000; Hickey and Golding, 2002; Hirst et al., 2002). The authors have followed the USEPA chronic criterion values for $\mathrm{Al}\left(87 \mu \mathrm{g} \mathrm{L}^{-1}\right), \mathrm{Fe}$ and $\mathrm{Mn}\left(1000 \mu \mathrm{g} \mathrm{L}^{-1}\right)$, whilst the criterion values for $\mathrm{Ag}\left(1.9 \mu \mathrm{g} \mathrm{L}^{-1}\right)$, As $\left(150 \mu \mathrm{g} \mathrm{L}^{-1}\right), \mathrm{Cd}\left(0.25 \mu \mathrm{g} \mathrm{L}{ }^{-1}\right)$, Co $\left(5.5 \mu \mathrm{g} \mathrm{L}{ }^{-1}\right), \mathrm{Cu}\left(9 \mu \mathrm{g} \mathrm{L}^{-1}\right), \mathrm{Pb}$ $\left(2.5 \mu \mathrm{g} \mathrm{L}^{-1}\right)$, Ni $\left(52 \mu \mathrm{g} \mathrm{L}^{-1}\right), \mathrm{Sb}\left(6 \mu \mathrm{g} \mathrm{L}^{-1}\right)$, and $\mathrm{Zn}\left(120 \mu \mathrm{g} \mathrm{L}^{-1}\right)$ were chosen according to the data published from USEPA $(1986,1999,2002)$. Metals/metalloids below the detection limit are not included in the CCU calculation. Assuming that toxic effects are additive the 1.0 value represents the limit from which would be expected to notice adverse effects on the aquatic organisms. Thus, background sites were defined for CCU values below 1.0 (Guasch et al., 2009). The low metal category consisted of those sites with a CCU ranging from 1.0 to 2.0; the medium metal category consisted of sites with CCU values between 2.0 and 10.0 (Guasch et al., 2009); and values higher than 10 are considered as belong to the high metal category.

The modified acid mine drainage index (MAMDI) (Kuma, 2011) was determined for the purpose of categorizing the water quality and to detect the impact of AMD in the stream waters at each sampling site. This estimation is based in the acid mine drainage index (AMDI) (Eq. (6)) proposed by Gray (1996). Few modifications were introduced in the original ADMI assumptions, basically associated with the number of variables in the definition of each parameter ( $q i)$ used and the respective parameter weighting factor (wi), since even with the introduction of a correction factor to the ADMI equation, to adjusts the missing variables, was not proven to be practical (Kuma, 2011).

AMDI $=\frac{\left.\left[\sum \text { (water quality scores }\right)\right]^{2}}{100}$

Thus, based on the modified water quality ratings (qiwi) defined by Kuma (2011) it was possible to achieve the correspondent water quality score of each parameter (the lower the score is, the more serious the contamination). With these score values was calculated de MAMDI (Eq. (6)) of each water sample.

\subsubsection{Speciation and saturation states of waters}

The PHREEQC code (version 2.0; Parkhurst and Apello, 1999) was used for calculating the activity and chemical speciation of dissolved species and the saturation index of minerals [SI = log (IAP / Ksp)], where SI is the saturation index, IAP is the ion activity product, and Ksp is the solid solubility product. The calculus were conducted with WATEQ4F (Ball and Nordstrom, 1991) thermodynamic database. Solubility constants [KS] from literature were used for other minerals not considered by the thermodynamic database used, such as schwertmannite. Zero, negative and positive SI values indicate that the solutions are theoretically in equilibrium, undersaturated, and supersaturated, respectively, with respect to a solid phase. Thus, a supersaturation state indicates that reaction will tend to proceed in the way of the precipitation of the considered solid phase (i.e. the solution does no have or show a low ability for the dissolution of that mineral phase), whereas the undersaturation state indicates the condition of solution to the dissolution of the respective solid phase. However, these index values are not strictly determinatives of precipitation or dissolution states, since these reactions depend also on the kinetics.

\section{Results}

4.1. Volcanic massive sulphide host rocks and waste pile material characterization

Largely unconsolidated and unvegetated waste piles of sulphide ore, sulphide-bearing waste material and non-mineralised host rock materials occur at the mine site. Representative samples collected from host rock material [phyllites and quartzites (PQ), quartz-feldspar porphyritic volcanics (Va1), felsic volcanics (Va2), gossan (Gos) and black shales with disseminated pyrite ore (BSPy)] were chemically analysed and the major and trace element concentrations are reported by Reis et al. (2012).

The volcanic massive sulphide host rock samples show, in general, low concentrations of trace metals. High concentrations of Ba were determined in $\mathrm{Va} 1$ and $\mathrm{Va} 2, \mathrm{Cu}$ and $\mathrm{Pb}$ in $\mathrm{Va} 2$, and $\mathrm{As}, \mathrm{Au}, \mathrm{Cu}, \mathrm{Hg}, \mathrm{Pb}$ and $\mathrm{Sb}$ in BSPy samples. The PQ samples show the highest $\mathrm{Zn}$ concentrations (Reis et al., 2012).

The E1, E2, E3, E4 and E4b waste classes are different in composition, showing high contents in Ag (1.5-100 mg kg-1), As (104$\left.1861 \mathrm{mg} \mathrm{kg}^{-1}\right), \mathrm{Cd}\left(0.1-4.0 \mathrm{mg} \mathrm{kg}^{-1}\right), \mathrm{Cu}\left(47-10,000 \mathrm{mg} \mathrm{kg}^{-1}\right), \mathrm{Hg}$ (1.4-100 mg kg-1), Pb (525-10,000 mg kg-1), Sb (9.2-703 mg kg-1) and $\mathrm{Zn}$ (39-4231 $\mathrm{mg} \mathrm{kg}^{-1}$ ) (Reis et al., 2012).

The E1 waste class is related with the main tailing (up to $6 \mathrm{~m}$ thick), which causes a strong impact on landscape. These wastes were produced by the extraction and metal recovery processes used to exploit the primary deposit are characterized by high amounts of coarse brittle sulphide ore (pyrite, chalcopyrite, galena, sphalerite, arsenopyrite, and minor tenantite) and high concentrations of $\mathrm{As}, \mathrm{Ba}, \mathrm{Cu}, \mathrm{Hg}, \mathrm{Pb}, \mathrm{Sb}$ and Sn. This waste material, located at the top of the central hill, lies under instable slope conditions, being deeply eroded and showing signals of leaching process by acid mine waters. In the base of the main tailing, wood channels (presently inactive) were used to transport enriched metals' acid waters to the $\mathrm{Cu}$ cementation tanks located in the eastern mine sector (Fig. 1).

The waste material corresponding to E2 class is located downstream from the mine and probably corresponds to a downslope transported material, linked to the mechanical erosion of the Caveira main tailing (E1). This material, defined by $<2 \mathrm{~cm}$ size fragments, got similar composition to E1 and is enriched in $\mathrm{Ag}, \mathrm{As}, \mathrm{Ba}, \mathrm{Cd}, \mathrm{Cu}, \mathrm{Hg}, \mathrm{Pb}, \mathrm{Sb}, \mathrm{Sn}$ and $\mathrm{Zn}$ (Reis et al., 2012). Secondary minerals as efflorescent salts occur as a result of weathering, oxidation and dissolution versus precipitation processes.

The E3 class is defined by a major percentage of host rocks and also include the wastes related to the gossan exploitation.

The E4 class, in the northern Caveira mine sector, consists of modern (XIX century) slag, linked to open-air pyrite roasting (teleras method). This roasting method was commonly used in IPB mines and consisted in slow open-air calcination of pyrite (Vara, 1963). The Roman slag wastes (E4b class - Fig. 1) are common in the eastern sector of the Caveira mine as in situ stable thin layers $(<2 \mathrm{~m})$, well vegetated by specific grass plants (Rumex). All these materials reveal high $\mathrm{As}, \mathrm{Cu}$, $\mathrm{Pb}, \mathrm{Sb}$ and $\mathrm{Zn}$ concentrations and show significant haematitic alteration and secondary Cu minerals. 


\subsection{Stream sediment sample characterization}

The stream sediment samples show a heterogeneous geochemical pattern (Table 2) with a large range of concentrations (56-420 mg kg-1 As, $106-1591 \mathrm{mg} \mathrm{kg}^{-1} \mathrm{Ba}, 65-642 \mathrm{mg} \mathrm{kg}^{-1} \mathrm{Cu}, 0.02-100 \mathrm{mg} \mathrm{kg}^{-1} \mathrm{Hg}$, 3-1000 $\mathrm{mg} \mathrm{kg}^{-1} \mathrm{~Pb}, 4-214 \mathrm{mg} \mathrm{kg}^{-1} \mathrm{Sb}, 132-482 \mathrm{mg} \mathrm{kg}^{-1} \mathrm{Zn}$ ). Among the three streams sampled, the highest values of metals/metalloids were recorded in sediments from the impacted stream by AMD (SS2, SS3, SS4, SS5 and SS6). The chemical enrichments relative to local background values measured in samples collected from the Canal stream, unaffected by mining activities (SS13 and SS14), can reach a maximum of 30 times for As, 4.2 times for $\mathrm{Ba}, 21$ times for $\mathrm{Cu}$, 182 times for $\mathrm{Hg}, 13$ times for $\mathrm{Pb}, 110$ times for $\mathrm{Sb}$ and 6 times for $\mathrm{Zn}$. Although reporting the contaminated stream sediments concentrations to the typical levels found in uncontaminated stream sediments presented by Reimann and de Caritat (1998) from Austria, the enrichments reach 210 times for As, 3 times for Ba, 34 times for $\mathrm{Cu}, 1111$ times for $\mathrm{Hg}, 84$ times for $\mathrm{Pb}, 110$ times for $\mathrm{Sb}$ and 6 times for Zn.

However, the stream sediment samples collected downstream (SS11) and upstream (SS12) the confluence of Grândola stream with the Sado river show low trace metals concentrations, except for $\mathrm{Cd}, \mathrm{Cu}$ and $\mathrm{Zn}$ (Table 2). The highest concentrations of Fe (7.65-37.3\%), Al (8.9-14.5\%) and S (0.42-9.9\%) in the sediments located around the mine waste and tailing impoundments are explained by the large amounts of Fe-oxyhydroxides and sulphates precipitated in the stream bottom. Stream sediments affected by Lousal and Caveira mines reveals that kaolinite, mica, chlorite and Fe-oxyhydroxides were the major mineral phases identified in the size fine fraction (Cardoso Fonseca and Ferreira da Silva, 2000).
In general, the amounts of S are higher in more contaminated samples since metals are preferably associated with sulphide minerals (Table 2). Contrary, the amounts of $C$ tends be higher in uncontaminated or low AMD impacted samples (Table 2), which is explained by the greater biological productivity in these streams, contrary to highly AMD impacted sites where the life proliferation is very limited. With exception of sample SS4, the LOI values are not highly variable, once the decrease of $\mathrm{C}$ species in contaminated samples is compensated by an increase in sulphur species and the opposite is found for uncontaminated samples (Table 2).

\subsection{Acidic mine water sample characterization}

Field parameters and chemical composition of the studied acid mine water samples are reported in Table 3.

The most important AMD discharges at the Caveira mine come from the leaching of the E1 tailing (AMW3) and from the impoundment (AMW4). The $\mathrm{pH}$ values measured on acidic waters emerging from the tailings range from 1.1 to 2.7. Also, a high EC (up to $76.4 \mathrm{mS} \mathrm{cm}^{-1}$ ) and a high concentration of dissolved $\mathrm{SO}_{4}$ (up to $49,920 \mathrm{mg} \mathrm{L}^{-1}$ ) and $\mathrm{Fe}$ (up to $\left.11,140 \mathrm{mg} \mathrm{L}^{-1}\right)$ were determined. A positive correlation $(\mathrm{r}=0.70$; $\mathrm{p}<0.05$ ) has been found between EC values of these waters and dissolved $\mathrm{SO}_{4}$, which confirms EC as a good indicator of the degree of contamination of the waters affected by AMD, especially when coupled with $\mathrm{pH}$ measurements (Sánchez-España et al., 2005). Trace elements are also significantly enriched in these acid waters and vary seasonally, being the high metal concentrations founded in winter and summer seasons (Table 3 ). The link between higher $\mathrm{SO}_{4}$ and metal/metalloid concentrations (Fig. 3) indicates an important oxidation and subsequent dissolution of sulphides (pyrite, chalcopyrite, sphalerite, galena and arsenopyrite).

Table 2

Major and trace element concentrations in the stream sediment samples (spring season) from Grândola, its tributary and Canal streams, and from Sado river.

\begin{tabular}{|c|c|c|c|c|c|c|c|c|c|c|c|c|c|c|}
\hline & & \multicolumn{5}{|c|}{ Affluent of Grândola stream } & \multicolumn{4}{|c|}{ Grândola stream } & \multirow{2}{*}{\multicolumn{2}{|c|}{ Sado river }} & \multirow{2}{*}{\multicolumn{2}{|c|}{ Background }} \\
\hline & & \multicolumn{9}{|c|}{ Impacted stream by AMD } & & & & \\
\hline \multicolumn{2}{|c|}{ Ref. samples } & SS1 & SS2 & SS3 & SS4 & SS5 & SS6 & SS8 & SS9 & SS10 & SS11 & SS12 & SS13 & SS14 \\
\hline \multicolumn{2}{|c|}{ Distance $(\mathrm{m})^{\mathrm{a}}$} & 0 & 275 & & & 775 & 1525 & 3275 & 9900 & 12,120 & 14,570 & 15,400 & & \\
\hline $\mathrm{SiO}_{2}$ & $\%$ & 62.65 & 52.28 & 65.61 & 5.66 & 55.83 & 66.52 & 72.88 & 68.51 & 73.51 & 74.44 & 73.79 & 62.53 & 79.63 \\
\hline $\mathrm{Al}_{2} \mathrm{O}_{3}$ & $\%$ & 18.4 & 27.77 & 12.07 & 2.39 & 5.02 & 5.71 & 10.59 & 11.68 & 9.3 & 9.61 & 9.62 & 13.96 & 8.81 \\
\hline $\mathrm{Fe}_{2} \mathrm{O}_{3}$ & $\%$ & 6.38 & 3.00 & 7.65 & 37.3 & 3.78 & 3.53 & 4.57 & 5.51 & 5.14 & 4.46 & 4.35 & 6.18 & 3.18 \\
\hline $\mathrm{MgO}$ & $\%$ & 0.49 & 1.03 & 0.29 & 0.74 & 0.12 & 0.14 & 0.77 & 0.94 & 0.63 & 0.70 & 0.70 & 1.68 & 0.75 \\
\hline $\mathrm{CaO}$ & $\%$ & 0.04 & 0.17 & 0.03 & 4.75 & 0.01 & 0.01 & 0.27 & 0.42 & 0.46 & 0.73 & 0.67 & 0.82 & 0.23 \\
\hline $\mathrm{Na}_{2} \mathrm{O}$ & $\%$ & 0.47 & 0.28 & 0.52 & 2.53 & 0.17 & 0.19 & 1.61 & 1.46 & 1.08 & 1.31 & 1.15 & 1.47 & 1.35 \\
\hline $\mathrm{K}_{2} \mathrm{O}$ & $\%$ & 3.54 & 1.75 & 2.81 & 0.77 & 1.21 & 1.41 & 1.62 & 1.75 & 1.94 & 1.53 & 1.48 & 1.93 & 1.31 \\
\hline $\mathrm{TiO}_{2}$ & $\%$ & 0.88 & 2.37 & 0.84 & 0.09 & 0.56 & 0.56 & 0.8 & 0.83 & 0.69 & 1.11 & 1.04 & 1.79 & 0.86 \\
\hline $\mathrm{P}_{2} \mathrm{O}_{5}$ & $\%$ & 0.08 & 0.18 & 0.09 & 0.07 & 0.05 & 0.06 & 0.17 & 0.18 & 0.16 & 0.12 & 0.14 & 0.16 & 0.11 \\
\hline $\mathrm{MnO}$ & $\%$ & 0.02 & 0.02 & 0.01 & 0.11 & 0.01 & 0.01 & 0.06 & 0.06 & 0.09 & 0.22 & 0.1 & 0.24 & 0.07 \\
\hline LOI & $\%$ & 6.90 & 10.80 & 9.60 & 34.70 & 11.50 & 9.50 & 6.50 & 8.40 & 6.90 & 5.60 & 6.80 & 9.10 & 3.50 \\
\hline TC & $\%$ & 0.60 & 0.06 & 1.26 & 0.30 & 0.44 & 0.51 & 1.48 & 1.70 & 1.88 & 1.03 & 1.57 & 2.00 & 0.47 \\
\hline TS & $\%$ & 0.02 & 0.42 & 1.00 & 9.92 & 3.93 & 2.53 & 0.06 & 0.05 & 0.01 & 0.03 & 0.04 & 0.01 & 0.01 \\
\hline $\mathrm{Ag}$ & $\mathrm{mg} \mathrm{kg}^{-1}$ & 0.4 & b.d.l. & 3.4 & 0.7 & 36.9 & 31.1 & 1.6 & 1.4 & 0.4 & b.d.l. & b.d.l. & 0.2 & 0.3 \\
\hline As & $\mathrm{mg} \mathrm{kg}^{-1}$ & 56 & 115 & 379 & 420 & 292 & 285 & 134 & 189 & 121 & 33 & 22 & 14 & 13 \\
\hline $\mathrm{Au}$ & $\mathrm{mg} \mathrm{kg}^{-1}$ & 9 & 1 & 35 & 24 & 291 & 263 & 29 & 28 & 8 & 2 & 4 & 3 & 5 \\
\hline $\mathrm{Ba}$ & $\mathrm{mg} \mathrm{kg}^{-1}$ & 504 & 1405 & 432 & 106 & 1591 & 1077 & 382 & 342 & 315 & 292 & 288 & 479 & 286 \\
\hline $\mathrm{Bi}$ & $\mathrm{mg} \mathrm{kg}^{-1}$ & 1.1 & 0.1 & 5.0 & 6.0 & 54.1 & 43.9 & 1.4 & 1.0 & 0.5 & 0.4 & 0.5 & 0.3 & 0.2 \\
\hline $\mathrm{Cd}$ & $\mathrm{mg} \mathrm{kg}^{-1}$ & 0.1 & 0.1 & 0.1 & 1.2 & 0.8 & 0.7 & 0.4 & 0.7 & 0.6 & 1.9 & 1.9 & 0.2 & 0.1 \\
\hline Co & $\mathrm{mg} \mathrm{kg}^{-1}$ & 11 & 13 & 3 & 17 & 2 & 2 & 11 & 13 & 12 & 32 & 35 & 25 & 10 \\
\hline $\mathrm{Cu}$ & $\mathrm{mg} \mathrm{kg}^{-1}$ & 65 & 642 & 97 & 246 & 111 & 72 & 113 & 139 & 98 & 135 & 136 & 46 & 16 \\
\hline $\mathrm{Hg}$ & $\mathrm{mg} \mathrm{kg}^{-1}$ & 0.67 & 0.02 & 4.32 & 0.73 & 100 & 100 & 5.19 & 4.46 & 1.67 & 0.21 & 0.09 & 0.22 & 0.88 \\
\hline $\mathrm{Nb}$ & $\mathrm{mg} \mathrm{kg}^{-1}$ & 20.9 & 25.5 & 18.2 & 2.2 & 16.0 & 13.5 & 12.2 & 12.7 & 9.2 & 11.4 & 11.1 & 27.1 & 11.6 \\
\hline $\mathrm{Ni}$ & $\mathrm{mg} \mathrm{kg}^{-1}$ & 16 & 20 & 3 & 7 & 2 & 2 & 18 & 22 & 18 & 22 & 23 & 48 & 18 \\
\hline $\mathrm{Pb}$ & $\mathrm{mg} \mathrm{kg}^{-1}$ & 159 & 3 & 2177 & 361 & 10,000 & 10,000 & 776 & 398 & 140 & 38 & 35 & 79 & 76 \\
\hline $\mathrm{Sb}$ & $\mathrm{mg} \mathrm{kg}^{-1}$ & 5.2 & 10.3 & 29.5 & 10.6 & 214.0 & 206.3 & 12.1 & 9.3 & 3.9 & 1.5 & 1.7 & 1.8 & 2.1 \\
\hline Sn & $\mathrm{mg} \mathrm{kg}^{-1}$ & 11 & 2 & 34 & 18 & 266 & 252 & 16 & 10 & 5 & 13 & 4 & 4 & 3 \\
\hline $\mathrm{Zn}$ & $\mathrm{mg} \mathrm{kg}^{-1}$ & 237 & 132 & 136 & 482 & 154 & 148 & 201 & 292 & 273 & 1025 & 822 & 107 & 59 \\
\hline $\mathrm{Zr}$ & $\mathrm{mg} \mathrm{kg}^{-1}$ & 389 & 135 & 411 & 23 & 239 & 226 & 317 & 253 & 186 & 319 & 240 & 210 & 393 \\
\hline
\end{tabular}

Abbreviations: b.d.l. - below detection limit); LOI - loss on ignition; TC - total carbon; TS - total sulphur.

a Distance from the open-pit. 
Table 3

Chemical analysis of AMD samples from two different sampling sites (AMW3, AMW4), collected at three seasonal periods.

\begin{tabular}{|c|c|c|c|c|c|c|c|}
\hline \multirow[t]{2}{*}{ Var } & \multirow[t]{2}{*}{ Units } & \multicolumn{2}{|l|}{ WIS } & \multicolumn{2}{|l|}{ SPS } & \multicolumn{2}{|l|}{ SUS } \\
\hline & & AMW3 & AMW4 & AMW3 & AMW4 & AMW3 & AMW4 \\
\hline $\mathrm{pH}$ & & 2.0 & 2.7 & 1.1 & 2.6 & 1.3 & 2.5 \\
\hline EC & $\mathrm{mS} \mathrm{cm}^{-1}$ & 76.1 & 1.8 & 76.4 & 2 & 71.5 & 2.26 \\
\hline $\mathrm{HCO}_{3}$ & $\mathrm{mg} \mathrm{L}^{-1}$ & 0 & 0 & 0 & 0 & 0 & 0 \\
\hline $\mathrm{Cl}$ & $\mathrm{mg} \mathrm{L}^{-1}$ & 0.1 & 19 & 1 & 4 & 1 & 1 \\
\hline $\mathrm{SO}_{4}$ & $\mathrm{mg} \mathrm{L}^{-1}$ & 49,920 & 756 & 9066 & 775 & 15,689 & 906 \\
\hline $\mathrm{Na}$ & $\mathrm{mg} \mathrm{L}^{-1}$ & 17 & 6 & 14 & 6 & 15 & 8 \\
\hline $\mathrm{K}$ & $\mathrm{mg} \mathrm{L}^{-1}$ & 43 & 0.3 & 30 & 0.4 & 29 & 1 \\
\hline $\mathrm{Mg}$ & $\mathrm{mg} \mathrm{L}^{-1}$ & 37 & 11 & 31 & 12 & 35 & 13 \\
\hline $\mathrm{Ca}$ & $\mathrm{mg} \mathrm{L}^{-1}$ & 19 & 12 & 13 & 12 & 15 & 12 \\
\hline $\mathrm{Al}$ & $\mathrm{mg} \mathrm{L}^{-1}$ & 490 & 41 & 350 & 43 & 418 & 44 \\
\hline As & $\mu \mathrm{g} \mathrm{L}^{-1}$ & 86,136 & 172 & 53,512 & 78 & 61,798 & 335 \\
\hline $\mathrm{Cd}$ & $\mu \mathrm{g} \mathrm{L}^{-1}$ & 691 & 14 & 191 & 15 & 429 & 18 \\
\hline Co & $\mu \mathrm{g} \mathrm{L}^{-1}$ & 504 & 61 & 95 & 57 & 319 & 66 \\
\hline $\mathrm{Cu}$ & $\mathrm{mg} \mathrm{L}^{-1}$ & 52.7 & 1.1 & 55.2 & 1.3 & 58.5 & 1.4 \\
\hline $\mathrm{Fe}$ & $\mathrm{mg} \mathrm{L}^{-1}$ & 11,140 & 80 & 3173 & 104 & 9486 & 150 \\
\hline $\mathrm{Hg}$ & $\mu g \mathrm{~L}^{-1}$ & b.l.d. & 0.3 & 0.1 & 0.3 & 0.1 & 0.1 \\
\hline $\mathrm{Mn}$ & $\mu \mathrm{g} \mathrm{L}^{-1}$ & 7237 & 2001 & 4866 & 2234 & 3239 & 1986 \\
\hline $\mathrm{Ni}$ & $\mu \mathrm{g} \mathrm{L}^{-1}$ & 692 & 74 & 338 & 103 & 414 & 93 \\
\hline $\mathrm{P}$ & $\mu \mathrm{g} \mathrm{L}^{-1}$ & 4994 & 50 & 5536 & 50 & 2041 & 50 \\
\hline $\mathrm{Pb}$ & $\mu \mathrm{g} \mathrm{L}^{-1}$ & 4519 & 1017 & 1691 & 850 & 3220 & 1918 \\
\hline V & $\mu \mathrm{g} \mathrm{L}^{-1}$ & 503 & 6 & 152 & 1 & 263 & 3 \\
\hline $\mathrm{Zn}$ & $\mathrm{mg} \mathrm{L}^{-1}$ & 313 & 6.89 & 280 & 11.6 & 278 & 10.5 \\
\hline
\end{tabular}

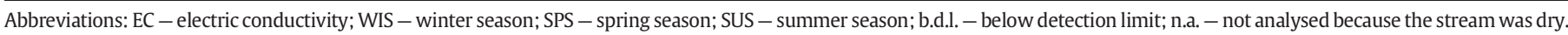

According to the conventional Piper diagram (Freeze and Cherry, 1979; Piper, 1944), these waters are classified as Fe$\mathrm{Mg}(\mathrm{Ca})$-sulphated type and are plotted in the field of "high acid/ extreme metal" in the Ficklin diagram (Ficklin et al., 1992)
(Fig. 4). In general, these AMD show concentrations of total dissolved solids (sulphate and metals) which are comprised within the ranges usually reported for VMS-type deposits (Plumlee et al., 1999).
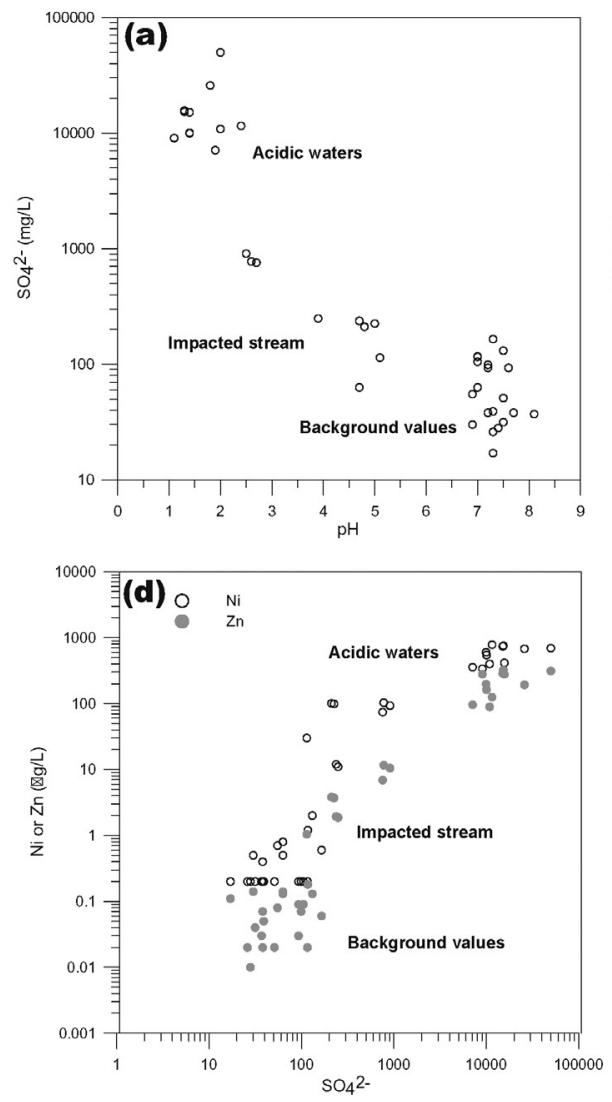
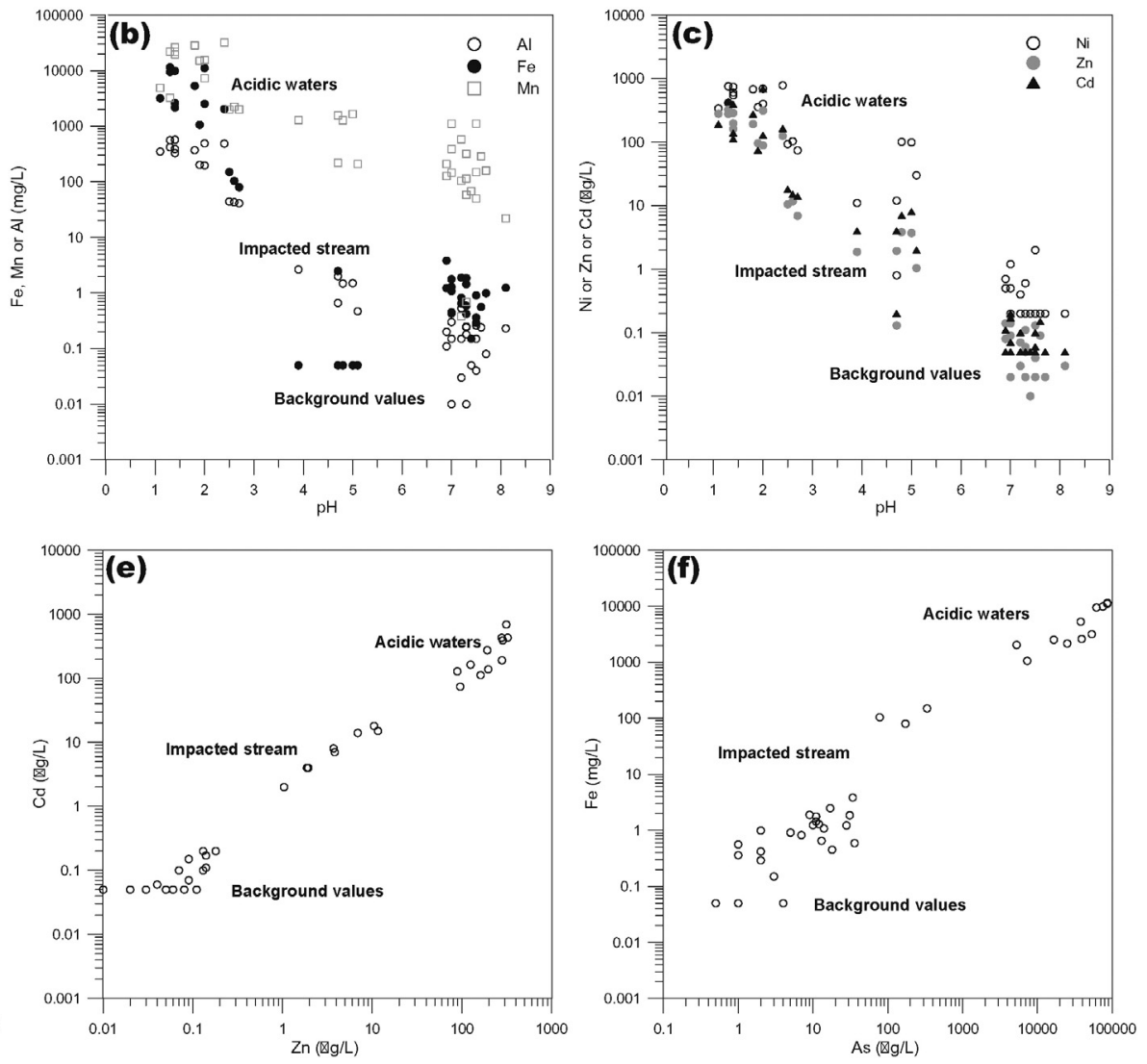

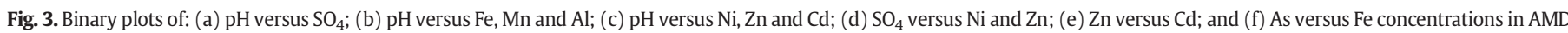
waters and stream waters of the impacted Grândola stream and its tributary and unimpacted sites. 


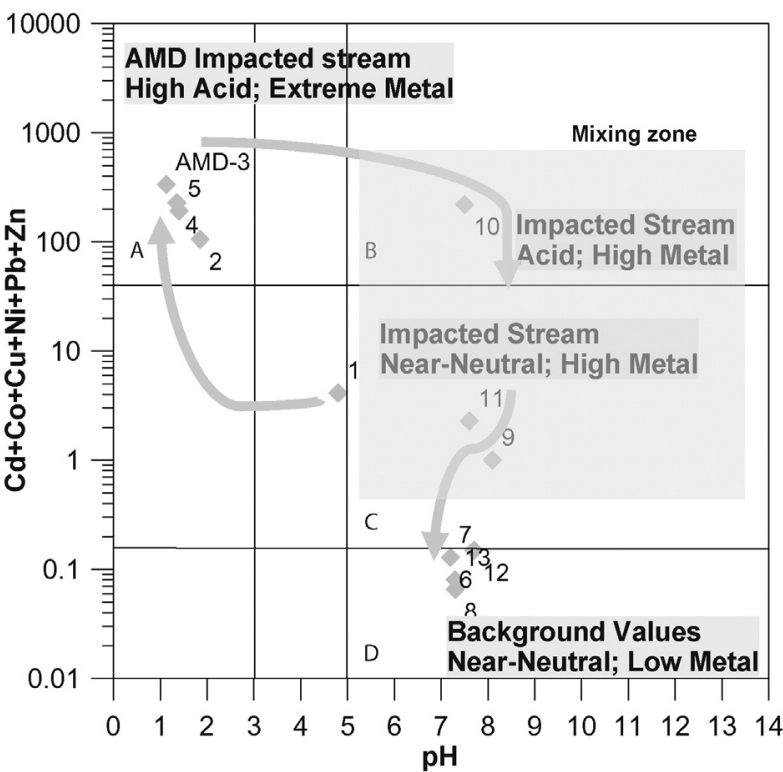

Fig. 4. Ficklin diagram showing the sum of dissolved trace metal concentrations $\left(\mathrm{mg} \mathrm{L}^{-1}\right)$ as a function of $\mathrm{pH}$ in AMD waters and stream waters of the impacted Grândola stream and its tributary and unimpacted sites (Plumlee et al., 1999).

\subsection{Stream water chemical characterization}

The physicochemical parameters and concentrations of major cations, anions and trace elements determined in the stream water samples are summarized in Table 4, according to winter, spring and summer collection periods. Data are grouped according to sampling site characteristics (i.e. impacted stream and mixing zone at the Grândola stream, and uncontaminated Sado river and Canal stream).

The impacted stream showed unusually high contents of trace metals, among the highest values reported for uncontaminated surface waters (Reimann and de Caritat, 1998). The highest concentrations of these potentially harmful elements were found in samples collected close to the main tailing deposit (SW2 to SW6), where values range from: 197-570 $\mathrm{mg} \mathrm{L}^{-1} \mathrm{Al}$; 5288-86,394 $\mu \mathrm{g} \mathrm{L}^{-1} \mathrm{As}$; 74-431 $\mu \mathrm{g} \mathrm{L} \mathrm{L}^{-1} \mathrm{Cd}$; $105-1082 \mu \mathrm{g} \mathrm{L}^{-1} \mathrm{Co} ; 7446-64,000 \mu \mathrm{g} \mathrm{L}^{-1} \mathrm{Cu} ; 1060-11,500 \mathrm{mg} \mathrm{L}^{-1}$ Fe; $<0.1-2.8 \mu \mathrm{g} \mathrm{L}^{-1} \mathrm{Hg} ; 15.0-32 \mathrm{mg} \mathrm{L}^{-1} \mathrm{Mn} ; 523-3749 \mu \mathrm{g} \mathrm{L}^{-1} \mathrm{~Pb}$; 89-324 $\mathrm{mg} \mathrm{L}^{-1} \mathrm{Zn}$; and $7113-15,300 \mathrm{mg} \mathrm{L}^{-1} \mathrm{SO}_{4}$. These concentrations exceed the background levels, taking as the average amounts of samples SW13 and SW14 by: Al 2736-71,250 times, As 594-9707 times, Cd 673-3918 times, Co 525-5410 times, Cu 677-5818 times, Fe 1233-13,372 times, Hg 14 times, Mn 167-356 times, Pb 15-110 times, $\mathrm{Zn} 2225-8100$ times and $\mathrm{SO}_{4} 245-528$ times. Also far exceeded the standards for drinking-waters $\left(10 \mu \mathrm{g} \mathrm{L}{ }^{-1}\right.$ for As; $5 \mu \mathrm{g} \mathrm{L}{ }^{-1}$ for Cd; $2 \mathrm{mg} \mathrm{L}^{-1}$ for $\mathrm{Cu} ; 200 \mu \mathrm{g} \mathrm{L}^{-1}$ for Fe $50 \mu_{\mathrm{g} \mathrm{L}}^{-1}$ for $\mathrm{Mn} ; 10 \mu \mathrm{g} \mathrm{L}^{-1}$ for $\mathrm{Pb} ; 5 \mu \mathrm{g} \mathrm{L}^{-1}$ for $\mathrm{Zn}$ ) and for irrigation waters (As $0.1 \mathrm{mg} \mathrm{L}^{-1}$; Cd $0.01 \mathrm{mg} \mathrm{L}^{-1}$; Cu $0.2 \mathrm{mg} \mathrm{L}^{-1}$; Fe $5 \mathrm{mg} \mathrm{L}^{-1}$; Mn $0.2 \mathrm{mg} \mathrm{L}^{-1} ; \mathrm{Zn}$ $2 \mathrm{mg} \mathrm{L}^{-1}$ ) (Dec. Lei 236/98; EU Council Directive 98/83/CE).

$\mathrm{The} \mathrm{Al}, \mathrm{Ca}, \mathrm{Mg}, \mathrm{Fe}, \mathrm{Si}$ and $\mathrm{SO}_{4}$, and trace element contents show a decreasing tendency downstream as the water moves away from the waste mine dumps, whereas the $\mathrm{pH}$ values tend to increase. These waters are plotted in the field of "acid/high metal" and also "near neutral/high metal" in the Ficklin diagram (Fig. 4).

The uncontaminated natural stream water samples (SW13 and SW14) are characterized by circumneutral $\mathrm{pH}$ values (7.3-7.7), low EC values (320-890 $\mu \mathrm{S} \mathrm{cm}^{-1}$ ), low $\mathrm{SO}_{4}$ and $\mathrm{Cl}$ contents and very low metal/metalloid concentrations. Most trace element concentrations are at or below the analytical detection limit (e.g. Bi and Cd) and are not significant contaminants in the stream prior to mixing with the acidic effluent. These waters are plotted in the field of "near neutral/low metal" in the Ficklin diagram (Fig. 4).

\section{Discussion}

The circulation and percolation of rainwater easily over and through the tailing materials is responsible for the significant chemical elements leaching, erosion and transport of tailing debris to areas nearby and downstream (Cardoso Fonseca and Ferreira da Silva, 2000; Ferreira da Silva et al., 2009; Mateus et al., 2008; Matos, 2006; Matos et al., 2003b). The heterogeneity of mining wastes in Caveira mine area facilitates the reaction of water and oxygen with fine brittle pyrite rich materials, promoting the formation of sulphuric acid and the decreasing of water $\mathrm{pH}$ at values less than 2.0 (Bell and Bullock, 1996). Also ferrous and ferric sulphate dissolution and ferric hydroxide precipitation give rise to acidic conditions in the tailing deposits. The increasing of $\mathrm{As}, \mathrm{Cd}$, $\mathrm{Co}, \mathrm{Cu}, \mathrm{Hg}, \mathrm{Mn}, \mathrm{Ni}, \mathrm{Pb}, \mathrm{Zn}$ and $\mathrm{SO}_{4}$ contents and $\mathrm{EC}$ values in waters indicates a progressive dissolution of polymetallic sulphide ores. Also the $\mathrm{Al}, \mathrm{Ca}, \mathrm{K}, \mathrm{Mg}$ and $\mathrm{Na}$ concentrations are indicative of the host rock mineral dissolution (volcaniclastic rocks, silicified vitric tuffs, black shales, etc.) enhanced by the low $\mathrm{pH}$ conditions.

These highly acidic waters from the tailing piles were observed to flow into the nearby streams, causing their contamination, where significant concentrations of $\mathrm{Al}, \mathrm{Cd}, \mathrm{Cu}, \mathrm{Fe}, \mathrm{Mn}, \mathrm{Pb}, \mathrm{Zn}$ and $\mathrm{SO}_{4}$ were observed in the stream waters near the main tailing deposit, and similar to other AMD case studies (Boult et al., 1994; Brake et al., 2001; Sainz et al., 2003; Sracek et al., 2004). The main input was observed near sample AMW3, where a disruption in the wall of the dam allowed the output of acidic water ( $\mathrm{pH} \sim 1$ ) with high concentrations of trace elements (Table 3 ). Also in samples SW2, SW5 and SW6 the pH values are very low (Table 4) indicating the influence of highly acidic waters draining from mine tailings.

The concentrations of the most harmful metals and metalloids are 15 to 71,250 times higher than the background levels (samples SW13 and SW14 - Table 4) and consistent with those expected in mining areas impacted by sulphide rich tailings.

Once the AMD sulphate rich waters mixture with the stream waters (affluent of Grândola stream) the concentration remained fairly constant until it was diluted somewhat by uncontaminated water from the Grândola stream, which causes a progressive neutralization and ion precipitation downstream (SW2 to SW10 - Fig. 2). The Grândola stream profile showing that near the main tailing deposit the stream waters are seriously contaminated with As and sulphide-related heavy metals (Table 4), where approximately $1 \mathrm{~km}$ downstream the $\mathrm{pH}$ value stills low. These particular conditions of the Caveira downstream area reflect the local topography and the reduced clean water affluent inputs.

The water collected in the Sado river, upstream the confluence with Grândola stream (sample SW11), showed that the concentrations of Al, $\mathrm{Cd}, \mathrm{Fe}, \mathrm{Pb}$ and $\mathrm{Zn}$ were higher than the background values presented by Ferreira da Silva et al. (2005) for the Sado river (Table 4). These values show the influence of the Lousal mine that are responsible for the increase of trace elements (mainly $\mathrm{Pb}$ and $\mathrm{Zn}$ ) in this river.

The waters from the Canal stream (samples SW13 and SW14) are mainly in the near-neutral and low metal field, since they are not under the influence of the mine. Hydrolysis of the alkali earth minerals may result in the formation of buffering complexes like bicarbonates, which maintain more or less constant the circumneutral $\mathrm{pH}$ of this stream, representing the original characteristics of natural waters from this site.

As shown in Tables 3 and 4, the chemical composition of the surface waters is not markedly conservative through the different seasons. In the summer the flow rate in the stream is reduced and the $\mathrm{pH}$ tends to decrease during this dry period, mainly in the zones closer to the tailings. Thus, the increase of sulphate and metals/metalloids in waters in summer is explained by a chemical saturation in waters due to evaporation processes, whilst in winter the high amounts of metals/metalloids and sulphate in the waters are explained by their release from sulphate efflorescence dissolution promoted by rainfalls, previously precipitated during the dry period, as described in other mining areas by several 
Table 4

Field measurement data and chemical composition of the stream water samples collected in the study area (winter, spring and summer periods).

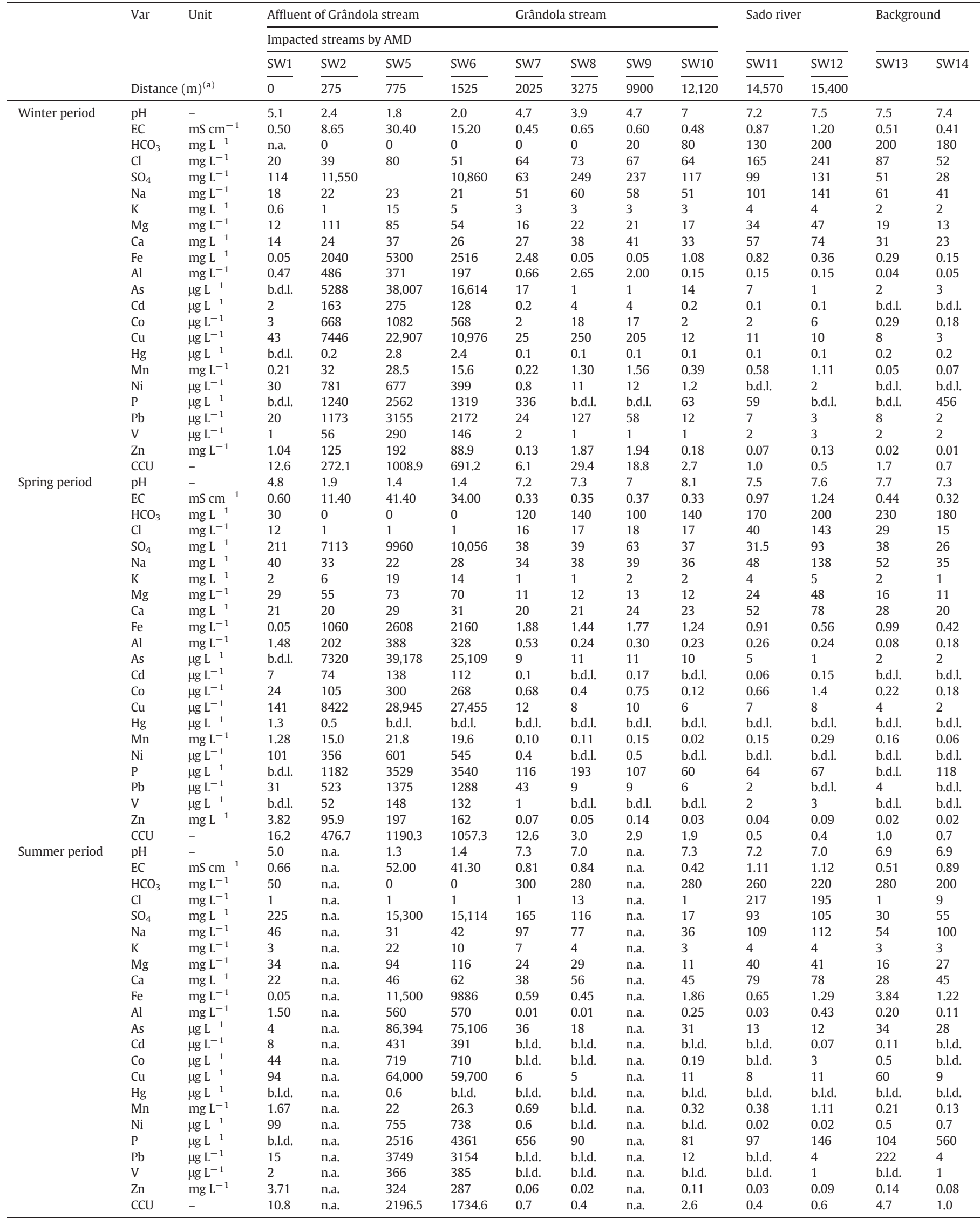

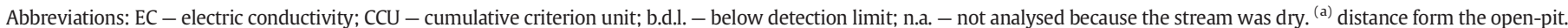


authors (e.g. Alpers et al., 1994; Kimball, 1999). For these reasons, summer and winter sampling periods show the highest metals and sulphate concentrations in acid mine waters, whereas in spring sampling period the dilution effects overlap to the fast efflorescent dissolution recorded in the winter period and the intense evaporation processes promoted by the high temperatures in summer (Table 3 ).

Otherwise, the stream waters collected in spring season (Table 4) show, in general, slightly higher metal contents than that ones collected in winter. This may be explain by the greater water input in main streams by their tributaries in winter, caused by rainfall episodes (more frequently in autumn and winter), promoting dilution effects, that at some point, surpass the effects caused by sulphate dissolution. In spring season, the increase of temperature and the reduction of rainfall episodes, cause a decrease of clean water influx to the streams affected by AMD, which lead to greater amounts of total dissolved solids in stream waters, with a cumulative trend until summer. This point out that different contamination patterns are expected according to waters typology (stream waters or tailing runoffs) along the year.

Iron is easily hydrolysed forming solid hydroxides when the acidic waters discharge to the higher pH stream waters (samples SW7 to SW10). The high $\mathrm{pH}$ of streams results in the precipitation of most of the metals, giving rise to low metal concentrations in the stream waters and high metal concentrations in the stream sediments (Tables 2 and 4). This agree with Chapman et al. (1983) who found that mechanisms of sorption, precipitation and dilution accounted for the attenuation of metals in AMD affected streams from New South Wales, Australia.

Considering the levels of the trace elements determined in the different geochemical compartments studied, three elements highlight as of the greatest concern, being $\mathrm{As}, \mathrm{Hg}$ and $\mathrm{Pb}$. In some cases, even in the samples representative of the background, the levels of these elements are significant high. Also Reis et al. (2012) pointed out these elements as the most important potentially harmful contaminants in soils for this mining area. A relevant aspect is related with $\mathrm{Hg}$, which shows low concentrations in the acid mine waters draining from the tailings (Table 3), but very high concentrations in the most acid stream waters during summer sampling period (Table 4). The source of $\mathrm{Hg}$ is probably associated with the BSPy rocks, as demonstrate by the high $\mathrm{Hg}$ concentrations in those samples as well in the E1 tailing (Reis et al., 2012). Cadmium is also particularly relevant in the waters with lowest $\mathrm{pH}$.

Water quality criteria for chemical elements, which represents levels that when exceeded may be harmful to aquatic organisms, were used in this study. As the criterion values are only available for individual elements, alternative models are necessary to estimate toxic effects of metal mixtures, hence the derivation of the CCU was used (Clements et al., 2000). The EPA metal thresholds considered are based on toxicity tests of species from different trophic levels, including macroinvertebrates (Hirst et al., 2002). The enrichment factors (CCU) calculated with respect to the EPA guidelines showed that the concentrations of $\mathrm{Al}, \mathrm{As}, \mathrm{Cd}, \mathrm{Cu}, \mathrm{Fe}, \mathrm{Mn}, \mathrm{Ni}, \mathrm{Pb}$ and $\mathrm{Zn}$ were enriched and exceeded their maximum permissible levels (Table 4).

According to the results, the sampling sites under influence of AMD discharges show CCU scores greater than 1 and slightly higher in summer than in winter and spring seasons (Table 4). Thus, exceeding the conservative estimation of the total metal concentration likely to cause harm to aquatic organisms (Clements et al., 2000). The CCU scores decreased from upstream to downstream in the three sampling seasons (Table 4; Fig. 5a). The winter results indicate that $\mathrm{Al}, \mathrm{Cd}, \mathrm{Cu}, \mathrm{Fe}, \mathrm{Pb}$ and $\mathrm{Zn}$ were the major cause of potential impairment and, to a lesser extent, $\mathrm{Mn}$ and Ni. The summer scores followed a similar trend, with $\mathrm{Al}$ and Fe remaining the major sources of potential toxicity. The scores were significantly higher at the area near the main tailing deposit, although the reference sites (SW13 and SW14) didn't show significant variation among the different seasons (except for sample SW14 in the summer season) (Table 4).

However the variability between AMW3 and AMW4 sites was always much higher than temporal changes, showing that during the year the volume of water percolation inside the tailing deposit remains constant, whilst in the studied streams (the impacted Grândola stream and its affluent and Sado river) the flow decreases in the summer period and low dilution is observed.

Fish and other macroscopic organisms are absent in the zone affected by AMD. According to Brake et al. (2001), the relative absence of aquatic life in this environment suggests that contamination has probably disrupted food chain relationships, discouraged animal habitation
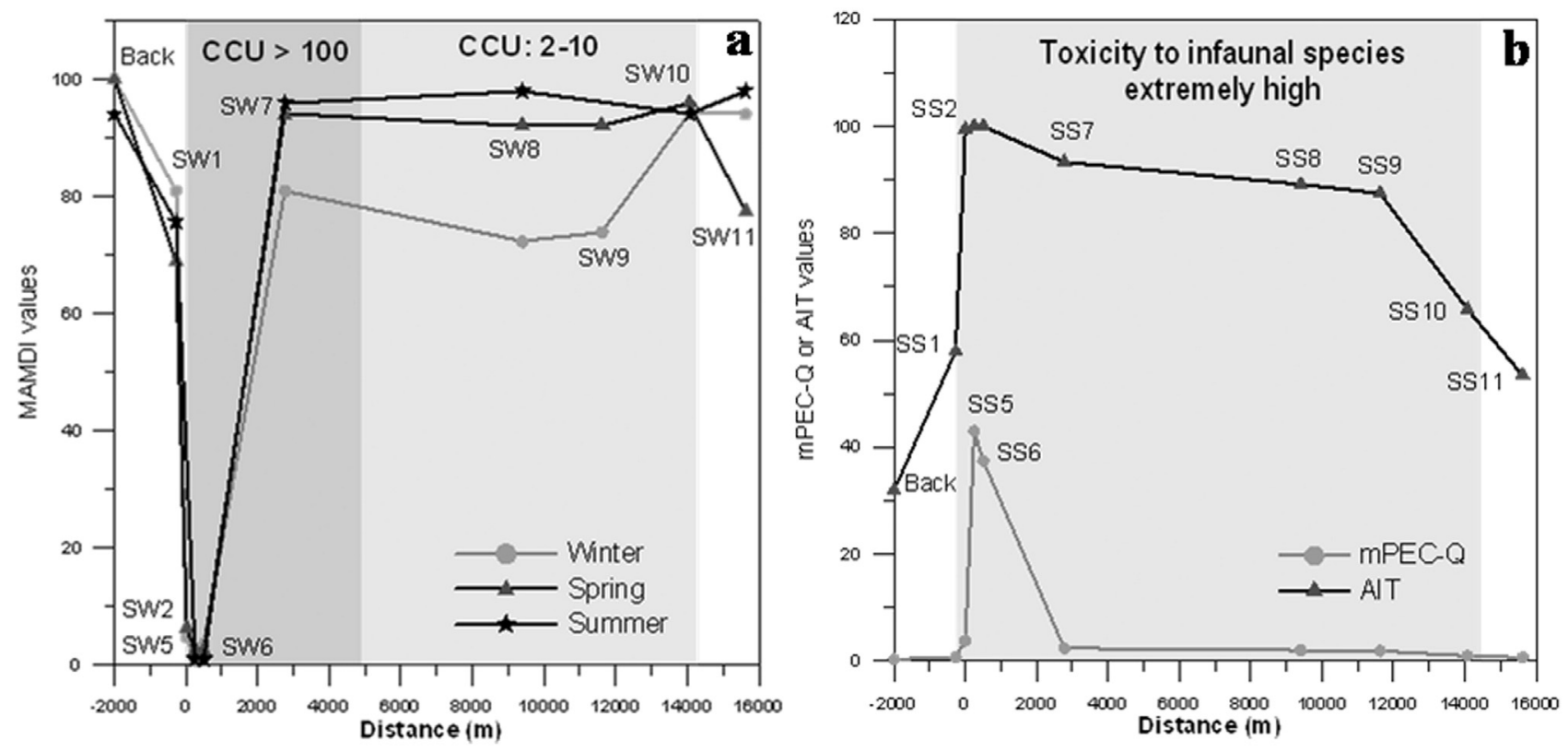

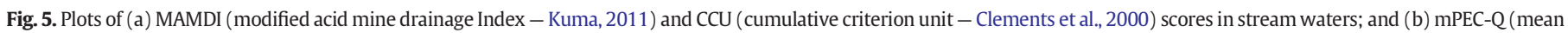
PEC quotient for metals) and AIT (Average Index of Toxicity - MacDonald et al., 2000) values in stream sediments against distance. 
and interfered with normal biogeochemical cycling of the stream system. Aluminium, for instance, has been shown to be lethal to fish at concentrations as low as $0.2 \mathrm{mg} \mathrm{L}^{-1}$ in a $\mathrm{pH}$ range of 4.4 to 5.9 (Cronan and Schofield, 1979). Witters et al. (1996), acute respiratory dysfunction and mortality of fish can occur in areas where aluminiumrich acidic waters mix with neutral waters.

The MAMDI showed very low scores for water samples near the tailings and similar among the different seasons. This is indicative of the high harmful contamination risk, which are in agreement with the high CCU scores. As the distance to the tailings increases a distinction of the MAMDI scores becomes evident, where the lowest values were found for winter, indicating a greater impact of these samples for AMD. However, at some points the CCU and MAMDI scores do not overlap as could be expected. This is due to the number and weights of parameters used for each index calculus, but also points out the relevance of the selection of the indexes that better defined the extension and magnitude of contamination.

High variations in chemical concentrations in sediment were found mainly due to the influence of the tailing piles scattered along the stream profile. The high concentrations of $\mathrm{As}, \mathrm{Ba}, \mathrm{Cd}, \mathrm{Cu}, \mathrm{Hg}, \mathrm{Pb}$ and $\mathrm{Sb}$ in the sediments reflect the mechanical weathering and dispersion of the tailing deposits (Table 2). According to Mateus et al. (2008) the dispersion of the trace elements, especially $\mathrm{Cu}, \mathrm{Pb}$ and $\mathrm{Zn}$ in sediments, is almost confined around the main tailing. The upstream sediments were found to exhibit a brownish natural colour, typical of clayey weathered ones, whilst in the downstream they were greyish in colour due to the presence of unoxidized sulphide material from the tailings.

In order to assess the quality of the streams at the mining area, total concentrations of $\mathrm{As}, \mathrm{Cd}, \mathrm{Co}, \mathrm{Cu}, \mathrm{Fe}, \mathrm{Mn}, \mathrm{Ni}, \mathrm{Pb}, \mathrm{Sb}$ and $\mathrm{Zn}$ were compared to the "Consensus-Based Sediment Quality Guidelines", developed by the Contaminated Sediment Standing Team (CSST, 2003). In Grândola stream, the PEC level is exceeded for $\mathrm{As}, \mathrm{Cu}, \mathrm{Fe}, \mathrm{Pb}, \mathrm{Sb}$ and $\mathrm{Zn}$ in most of the analysed samples and punctually for $\mathrm{Ni}$ and $\mathrm{Cd}$. MacDonald et al. (2000) propose an incidence of toxicity index allowing the quantification of potential contamination that gives a better perception of the degree of contamination at the site. The AIT results show that the impacted streams range from 80 to $100 \%$ (Fig. $5 \mathrm{~b}$ ) revealing that toxicity to fauna is extremely high. Although the concentration of metal/metalloid was being reduced in waters with distance, the $\mathrm{pH}$ increase causes their precipitation on sediments.

In fact, water-sediment interactions are crucial in the metal/metalloid behaviour and mobility. In acid sulphate drainage waters the solubility appears to be controlled by a variety of $\mathrm{Al} / \mathrm{Fe}$ oxides, oxyhydroxides, and sulphate phases as goethite, gibbsite, alunite, and jurbanite (Karathanasis et al., 1988; Monterroso et al., 1994). Probably, the most widespread feature of the study area is the ubiquitous presence of yellow to reddish-brown sediments in the banks of the rivers affected by AMD. These so-called "ochre precipitates" consist of Fe-phases precipitated from the AMD. In contrast with other well crystallized products of pyrite oxidation, such as hematite or goethite, these mine drainage minerals (MDM; Murad et al., 1994) consist of poorly crystallized oxyhydroxides and oxyhydroxysulphates of fibrous to spherical morphology such as ferrihydrite and schwertmannite, in addition to jarosite and goethite, showing extremely small particle size $(<1 \mathrm{~nm}$ spherical particle diameter) (Bigham et al., 1990, 1994, 1996; Carlson and Schwertmann, 1981; Dold, 2003; Fukushi et al., 2003; Kawano and Tomita, 2001; Majzlan et al., 2004; Murad et al., 1994; Nordstrom and Alpers, 1999; Regenspurg et al., 2004; Williams et al., 2002; Yu et al., 1999), which greatly enhance the reactive surface area, allowing the metal adsorption to these mineral phases.

An equilibrium mass-balance model has been used to calculate the elemental aqueous speciation and the stability of solid phases with respect to the dissolved constituents. The geochemical speciation model PHREEQC (Parkhurst and Appelo, 1999) was used to calculate the distribution of species and the values of saturation index (SI) for certain minerals.

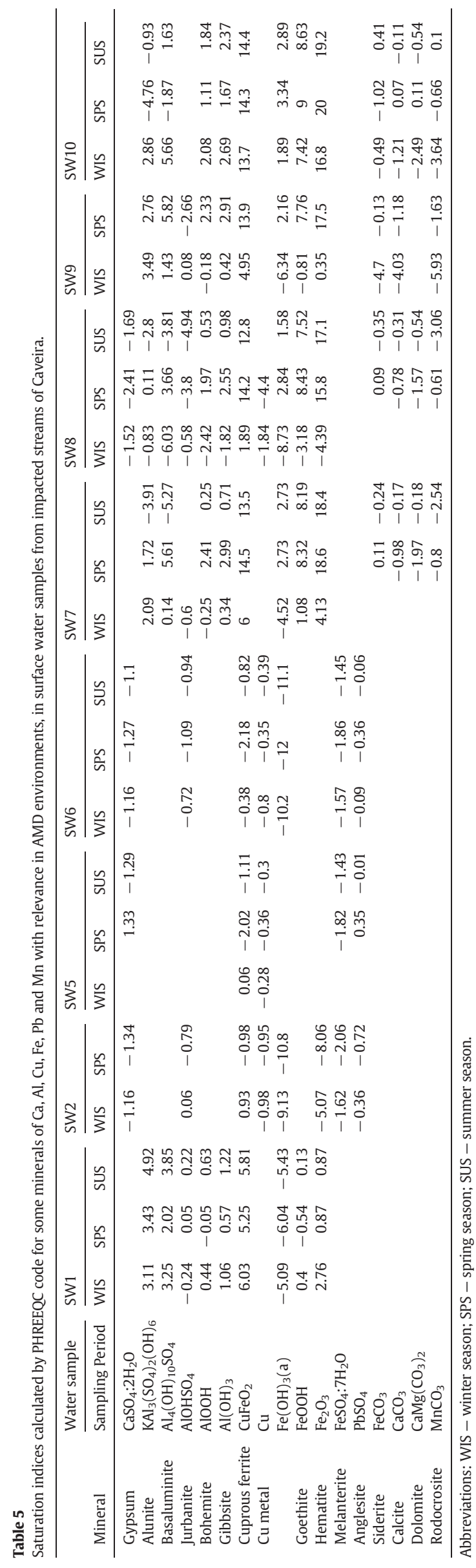


The geochemical prediction indicates that the dissolved metals in the acid mine waters from the impacted and Grândola streams are likely present in the form of their individual free ions $\left(\mathrm{Me}^{\mathrm{n}+}\right)$. Equilibriumspeciation modelling indicates that most of the samples collected in the Grândola stream were oversaturated with respect to gibbsite, goethite and amorphous $\mathrm{Fe}(\mathrm{OH})_{3}$ (Table 5). Langmuir and Whittemore (1971) suggest that $\mathrm{Fe}(\mathrm{OH})_{3}$ and poorly crystalline goethite are the first ferric phases to precipitate in streams impacted by acid mine waters, which tends to be converted into more stable phases over time, such as crystalline goethite or hematite. Overall, SI values (Table 5) were lower in winter and higher in spring, with respect to Fe-oxyhydroxides, which was in agreement with MAMDI scores that tend to be lower in winter, indicating greater metal/metalloid dissolution in waters. Almost all the samples were strongly oversaturated in $\mathrm{CuFeO}_{2}$ (sample $\mathrm{SW} 6$ is the only one that was undersaturated for all sampling periods). Calcite was near saturation in samples SW7, SW8, SW10 and SW11 in summer, whereas S10 was even oversaturated for calcite and dolomite in spring. Samples SW2, SW5 and SW6 were the only ones where $\mathrm{Cu}$ (metal) and $\mathrm{PbSO}_{4}$ were close saturation. The SW5 sample (in spring) is oversaturated in relation to gypsum.

At Caveira mining site, during dry periods, water flowing from the tailings and dam forms small dispersed ponds throughout the Caveira site. Evaporation of these waters (in dry periods temperature is higher than $30{ }^{\circ} \mathrm{C}$ ) causes co-precipitation of metal ions in the sulphate efflorescences, mainly in melanterite $\left(\mathrm{FeSO}_{4} \cdot 7 \mathrm{H}_{2} \mathrm{O}\right)$, but other efflorescent salts are observed such as rozenite $\left(\mathrm{FeSO}_{4} \cdot 4 \mathrm{H}_{2} \mathrm{O}\right)$, hexahydrite $\left(\mathrm{MgSO}_{4} \cdot 6 \mathrm{H}_{2} \mathrm{O}\right)$, epsomite $\left(\mathrm{MgSO}_{4} \cdot 7 \mathrm{H}_{2} \mathrm{O}\right)$ and gypsum $\left(\mathrm{CaSO}_{4} \cdot 2 \mathrm{H}_{2} \mathrm{O}\right)$. These sulphate minerals are important as both sinks of metals and acidity during precipitation. Although, due to the ephemeral nature of the most of these minerals (highly soluble), sulphate and metal ions are fast released when exposed to moisture (Cravotta, 1994). The particular salts precipitated at each site are a function of local solution composition, $\mathrm{pH}$ and relative humidity. They play an important role in the cycling of trace metals between aqueous and solid solutions (Jambor et al., 2000).

In general, based in these water: sediment concentration ratios, the most conservative elements (less affected by $\mathrm{pH}$ changes) in the water samples analysed were $\mathrm{As}<\mathrm{K}<\mathrm{Na}<\mathrm{Ca}<\mathrm{Mg}<\mathrm{Fe}<\mathrm{Pb}$, whereas the less conservative (more affected by $\mathrm{pH}$ changes) were $\mathrm{Cd}>\mathrm{Ni}>\mathrm{Zn}>\mathrm{Co}>\mathrm{Mn}>\mathrm{Cu}$. Aluminium and $\mathrm{Hg}$ precipitations are moderately affected by $\mathrm{pH}$ modifications in waters. This is an important aspect to take into consideration because despite the fact that concentrations of trace elements are higher in acid water conditions, for some potential harmful elements, such as As and $\mathrm{Hg}$, the precipitation on sediments is not highly dependent on $\mathrm{pH}$ variations. This is a matter of concern since $\mathrm{pH}$ is one of the remediation processes most used for the reduction of metal/metalloid concentrations in contaminated waters.

\section{Conclusions}

The Caveira mining area is under extremely environmental risk, mainly caused by AMD processes and metal/metalloid contamination in waters, sediments and soils that greatly affects the biota and the ecosystems surrounding the mine site.

The higher element concentrations are observed in the Grândola stream close to the old mine works. The patterns of these elements in the stream sediments and surface waters located downstream and downslope of the tailing site suggest that the dispersion is greatly controlled by erosion and transport of tailing materials and by the action of strong acid waters formed from the sulphide oxidation. Levels of chronic pollution by dissolved metals determined by CCU and MAMDI scores illustrate significant temporal differences between sampling sites and seasons, suggesting potential chronic toxicity at all sites, particularly within the impacted stream and most harmful during winter season. Although punctual distinctions in the classification of the environmental risk for biota is possible using both indexes.
The rainy and dry seasons are the most problematic periods due to the dissolution of efflorescent salts that are important sinks of metals and acidity, and due to the increase of water concentration favoured by evaporation processes, respectively. In periods between these two extreme season periods (rainy and dryness) the contamination impacts are attenuated due to the persistence of dilution effects and low evaporation (temperate situations).

For a successful reclamation of the Caveira abandoned mine, a proper rehabilitation plan should be defined, which is only possible if contamination processes are conveniently understood. The determination of risk assessment indexes for waters and sediments revealed to be useful to global definition of the magnitude and extension of the contamination. Although the differences found in scores between different indexes also pointed out that a proper site evaluation should include a cross data of precipitation along the year and the influx along the stream profiles, receiving or affected by tailing materials and AMD.

\section{Acknowledgements}

This study was financially supported with funds provided by IAPMEI (Instituto de Apoio às Pequenas e Médias Empresas e ao Investimento Ministério da Economia). Particular acknowledgments are addressed to Instituto Geológico e Mineiro (presently LNEG - Laboratório Nacional de Energia e Geologia) for authorizing the use and publication of the geochemical and hydrochemical data from "Estudo do Controle Ambiental nas áreas mineiras abandonadas de Lousal e Caveira” project.

\section{References}

Alpers, C.N., Nordstrom, D.K., Thompson, J.M., 1994. Seasonal variations of Zn/Cu ratios in acid mine water from Iron Mountain, California. In: Alpers, C.N., Blowes, D.W. (Eds.), American Chemical Society Symposium Series, Washington D.C. 1994 550, pp. 324-344

Alvarez, R., Ordoñez, A., Loredo, J., 2006. Geochemical assessment of an arsenic mine adjacent to a water reservoir (Léon, Spain). Environ. Geol. 50 (6), 873-884.

ASTM, 1984. American Society for Testing Materials, Annual Book of ASTM Standards. Water Environ. Technol. 11.01

Ball, J.W., Nordstrom, D.K., 1991. User's manual for WATEQ4F with revised thermodynamic data base and test cases for calculating speciation of major, trace, and redox elements in natural waters. U.S. Geological Survey Open-File Report, pp. 91-183.

Bell, F.G., Bullock, S.E.T., 1996. The problems of acid mine drainage, with an illustrative case history. Environ. Eng. Geosci. II(3), 369-392.

Bigham, J.M., Nordstrom, D.K., 2000. Iron and aluminium hydroxysulfates from acid sulfate waters. In: Alpers, C.N., Jambor, J.L., Nordstrom, D.K. (Eds.), Sulfate Minerals Crystallography, Geochemistry, and Environmental SignificanceReviews in Mineralogy \& Geochemistry. vol. 40. The Mineralogical Society of America and Geochemical Society, Washington, D.C., pp. 351-403.

Bigham, J.M., Schwertmann, U., Carlson, L., Murad, E., 1990. A poorly crystallized oxyhydroxyulfate of iron formed by bacterial oxidation of $\mathrm{Fe}(\mathrm{II})$ in acid mine waters. Geochim. Cosmochim. Acta 54, 2743-2758.

Bigham, J.M., Carlson, L., Murad, E., 1994. Schwertmannite, a new iron oxyhydroxysulphate from Pyhäsalmi, Finland, and other localities. Mineral. Mag. 58, 641-648.

Bigham, J.M., Schwertmann, U., Traina, S.J., Winland, R.L., Wolf, M., 1996. Schwertmannite and the chemical modeling of iron in acid sulfate waters. Geochim. Cosmochim. Acta 60, 2111-2121.

Boult, S., Collins, N.D., White, K.N., Curtis, C.D., 1994. Metal transport in a stream polluted by acid mine drainage - the Afon Goch, Anglesey, UK. Environ. Pollut. 84, 279-284.

Brake, S.S., Connors, K.A., Romberger, S.B., 2001. A river runs through it: impact of acid mine drainage on the geochemistry of West Little Sugar Creek pre- and post-reclamation at the Green Valley coal mine, Indiana, USA. Environ. Geol. 40, 1471-1481.

Cardoso Fonseca, E., Ferreira da Silva, E., 2000. Estudo de controle ambiental nas áreas mineiras abandonadas de Lousal e Caveira. Relatório Final da Universidade de Aveiro, Portugal (in portuguese).

Carlson, L., Schwertmann, U., 1981. Natural ferrihydrites in surface deposits from Finland and their association with silica. Geochim. Cosmochim. Acta 45, 421-429.

Castelo Branco, 1994. Área de Prospecção e pesquisa de Grândola-Alcácer. SMRA (Rio Tinto), Relatório Interno $1^{\circ}$ Sem. Arq. INETI.

Chapman, B.M., Jones, D.R., Jung, R.F., 1983. Processes controlling metal ion attenuation in (AMD) streams. Geochim. Cosmochim. Acta 47, 1959-1973.

Chon, H.T., Kim, J.Y., Choi, S.Y., 1999. Hydrogeochemical characteristics of acid mine drainage around the abandoned Youngdong coal mine in Korea. Resour. Geol. 49, 113-120.

Clements, W.H., Carlisle, D.M., Lazorchak, J.M., Johnson, P.C., 2000. Heavy metals structure benthic communities in Colorado mountain streams. Ecol. Appl. 10, 626-638.

Cravotta III, C.A., 1994. Secondary iron-sulfate minerals as sources of sulfate and acidity and the geochemical evolution of acidic ground water at a reclaimed surface coal mine in Pennsylvania. In: Alpers, C.N., Blowes, D.W. (Eds.), Environmental Geochemistry of Sulfide Oxidation. American Chemical Society Symposium Series 550, pp. 345-364 (Washington DC). 
Cronan, C.S., Schofield, C.L., 1979. Aluminium leaching response to acid precipitation: effects on high-elevation watersheds in the northeast. Science 204, 304-306.

CSST, 2003. Consensus Based Sediment Quality Guidelines: Recommendations for Use \& Application. Department of Natural Resources, Wisconsin, p. 35.

Decreto-Lei n²36/98, 1998. Diário da República de Portugal, I Série-A, n 176, 1 Agosto 1998, Portugal.

Di Toro, D.M., Mahoney, J.D., Scott, K.J., Hicks, J.B., Mays, S.M., Redmond, M.S., 1990. Toxicity of cadmium in sediments-the role of acid-volatile sulphide. Environ. Toxicol. Chem. 9, 1487-1502.

Council Directive 98/83/CE, 1998. European Union Council Directive on the Quality of Water Intended for Human Consumption of 3 November, Brussels.

Dold, B., 2003. Dissolution kinetics of schwertmannite and ferrihydrite in oxidized mine samples and their detection by differential X-ray diffraction (DXRD). Appl. Geochem. $18,1531-1540$.

Ferreira da Silva, E., Matos, J., Patinha, C., Reis, P., Cardoso Fonseca, E., 2005. The effect of unconfined mine tailings on the geochemistry of soils, sediments and surface waters of the Lousal area (Iberian Pyrite Belt, Southern Portugal). Land Degrad. Dev. 16 (2), 213-228.

Ferreira da Silva, E.A., Bobos, I., Matos, J.X., Patinha, C., Reis, A.P., Fonseca, E.C., 2009. Mineralogy and geochemistry of trace metals and REE in volcanic massive sulfide host rocks, stream sediments, stream waters and acid mine drainage from the Lousal mine area (Iberian Pyrite Belt, Portugal). Appl. Geochem. 24, 383-401.

Ficklin, W.H., Plumlee, G.S., Smith, K.S., McHugh, J.B., 1992. Geochemical classification of mine drainages and natural drainages in mineralized areas. Proceedings of the 7th International Symposium on Water-Rock Interaction. Balkema, Rotterdam, pp. 381-384

Freeze, R.A., Cherry, J.A., 1979. Groundwater. Prentice-Hall (604 pp.).

Fukushi, K., Sasaki, M., Sato, T., Yanese, N., Amano, H., Ikeda, H., 2003. A natural attenuation of arsenic in drainage from an abandoned arsenic mine dump. Appl. Geochem. 18, 1267-1278.

Gray, N.F., 1996. The use of objective index for the assessment of the contamination of surface water and groundwater by acid mine drainage. Water Environ. J. 10 (5), 332-340.

Guasch, H., Leira, M., Montuelle, B., Geiszinger, A., Roulier, J.L., Tornés, E., Serra, A., 2009. Use of multivariate analyses to investigate the contribution of metal pollution to diatom species composition: search for the most appropriate cases and explanatory variables. Hydrobiologia 627, 143-158.

Herr, C., Gray, N.F., 1996. Seasonal variation of metal contamination of riverine sediments below a copper and sulphur mine in south-east Ireland. Water Sci. Technol. 33 (6), 255-261.

Hickey, C.W., Golding, L.A., 2002. Response of macroinvertebrates to copper and zinc in a stream mesocosm. Environ. Toxicol. Chem. 21, 1854-1863.

Hirst, H., Juttner, I., Ormerod, S.J., 2002. Comparing the responses of diatoms and macroinvertebrates to metals in upland streams of Wales and Cornwall. Freshw. Biol. 47, $1752-1765$.

Jambor, J.L., Nordstrom, D.K., Alpers, C.N., 2000. Metal-sulfates salts from sulphide mineral oxidation. In: Alpers, C.N., Jambor, J.L., Nordstrom, D.K. (Eds.), Sulfate Minerals - Crystallography, Geochemistry, and Environmental SignificanceReviews in Mineralogy \& Geochemistry vol. 40. The Mineralogical Society of America and Geochemical Society, Washington, D.C., pp. 303-350.

Jönsson, J., Jönsson, J., Lovgren, L., 2006. Precipitation of secondary Fe(III) minerals from acid mine drainage. Appl. Geochem. 21, 437-445.

Karathanasis, A.D., Evangelou, V.P., Thompson, Y.L., 1988. Aluminium and iron equilibria in soil solutions and surface waters of acid mine watersheds. J. Environ. Qual. 17, 534-543.

Kawano, M., Tomita, K., 2001. Geochemical modeling of bacterially induced mineralization of schwertmannite and jarosite in sulfuric acid spring water. Am. Mineral. 86, 1156-1165.

Kim, J.J., Kim, S.J., Choo, C.O., 2003. Seasonal change of mineral precipitates from the coal mine drainage in the Taebaek coal field, South Korea. Geochem. J. 37, 109-121.

Kimball, B.A., 1999. Seasonal variation in metal concentrations in a stream affected by acid mine drainage, St. Kevin Gulch, Colorado. In: Filipek, L.H., Plumlee, G.S. (Eds.), The Environmental Geochemistry of Mineral Deposits, Part B. Case Studies and Research Topics, Society of Economic Geologists, Reviews in Economic Geology 6B, pp. 467-477.

Kralik, M., 1999. A rapid procedure for environmental sampling and evaluation of polluted sediments. Appl. Geochem. 14, 807-816.

Kuma, J.S., 2011. Numerical indices of the severity of acidic mine drainage: broadening the applicability of the Gray acid mine drainage index. Mine Water Environ. 30, 67-74.

Langmuir, D., Whittemor, D.O., 1971. Variations in the stability of precipitated ferric oxyhydroxides. In: Hem, J.D. (Ed.), Nonequilibrium Systems in Natural Waters Chemistry. Advances in Chemistry Series 106, pp. 209-234

MacDonald, D.D., Ingersoll, C.G., Berger, T.A., 2000. Development and evaluation of consensus based sediment quality guidelines for freshwater ecosystems. Arch. Environ. Contam. Toxicol. 39, 20-31.

Majzlan, J., Navrotsky, A., Schwertmann, U., 2004. Thermodynamics of iron oxides: part III. Enthalpies of formation and stability of ferrihydrite $\left(\mathrm{Fe}(\mathrm{OH})_{3}\right)$, schwertmannite $\left(\mathrm{FeO}(\mathrm{OH})_{3 / 4}\left(\mathrm{SO}_{4}\right)_{1 / 8}\right)$, and $\varepsilon-\mathrm{Fe}_{2} \mathrm{O}_{3}$. Geochim. Cosmochim. Acta 68 (5), 1049-1059.

Martins, L., Oliveira, D., 2000. Exploration and Mining. Instituto Geológico e Mineiro, Lisboa (20 pp.)

Mateus, A., Figueiras, J., Matos, J.X., Gonçalves, M.A., Lopes, R., Labaredas, J., Beleque, A 2008. Condicionantes impostas à dispersão de metais acumulados em escombreiras: o exemplo de Caveira (Faixa Piritosa Ibérica). A Terra: Conflitos e Ordem. Livro de Homenagem ao Professor Ferreira Soares. Museu Mineralógico e Geológico da Universidade de Coimbra, Portugal, pp. 373-382.

Matos, J.X. (2006) Carta geológica e mineira da mina de Caveira, Escala 1:5000. INETI.
Matos, J.X., Martins, L., 2006. Reabilitação ambiental de áreas mineiras do sector português da Faixa Piritosa Ibérica: estado da arte e perspectivas futuras. Boletin Geológico y Minero España 117(2). IGME, Spain, pp. 289-304.

Matos, J.X., Oliveira, V., 2003. Mina do Lousal (Faixa Piritosa Ibérica) - Percurso geológico e mineiro pelas cortas e galerias da antiga mina. Museo Geominero $n^{\circ} 2$. IGME, Madrid, pp. 117-128.

Matos, J.X., Barriga, F.J.A.S., Oliveira, V., 2003a. Alunite Veins Versus Supergene Kaolinite Halloysite Alteration in the Lagoa Salgada, Algares and S. João (Aljustrel) and S. Domingos Massive Sulphide Deposits, Iberian Pyrite Belt, Portugal vol. V. Ciências da Terra (UNL), Lisboa, pp. B56-B59.

Matos, J.X., Petersen, E.U., Chávez, W.X., 2003b. Portuguese mining sites. In: Domingos, S Corvo, Neves, Aljustrel, Lousal, Caveira (Eds.), Environmental Geochemistry Field Course - Iberian Pyrite Belt Society of Economic Geologists Guidebook. IGM Portugal (18 pp.).

Matos, J.X., Martins, A., Rego, M., Mateus, A., Pinto, A., Figueiras, J., Silva, E., 2008a. Roman slag mine wastes distribution in the Portuguese sector of the Iberian Pyrite Belt. V Congresso International SEDPGYM Minería y Metalurgia Históricas SW Europeo, León, Spain, p. 45.

Matos, J.X., Martins, L.P., Oliveira, J.T., Pereira, Z., Batista, M.J., Quental, L., 2008b. Rota da pirite no sector português da Faixa Piritosa Ibérica, desafios para um desenvolvimento sustentado do turismo geológico e mineiro. In: Carrion, P. (Ed.), Rutas Minerales en Iberoamérica. Projecto RUMYS, programa CYTED, Escola. Superior Politécnica del Litoral, Guayaquil, Equador, pp. 136-155.

Matzke, K., 1971. Mina do Lousal. Principais Jazigos Minerais do Sul de Portugal, Livro-Guia $\mathrm{n}^{\circ} 4$ pp. $25-32$.

Monterroso, C., Alvarez, E., Macías, F., 1994. Speciation and solubility controls of Al and Fe in minesoil solutions. Sci. Total Environ. 158, 31-43.

Morais, M., Pinto, P., Guilherme, P., Rosado, J., Antunes, I., 2004. Assessment of temporary streams: the robustness of metric and multimetric indices under different hydrological conditions. Hydrobiologia 516, 229-249.

Murad, E., Schwertmann, U., Bigham, J.M., Carlson, L., 1994. Mineralogical characteristics of poorly crystallized precipitates formed by oxidation of Fe(II) in acid sulphate waters. In: Alpers, CN. Blowes, D.W. (Eds.), Environmental Geochemistry of Sulphide Oxidation. American Chemical Society Symposium Series, Washington D.C. 550 pp. 190-200.

Nordstrom, D.K. Alpers, C.N 1999. Geochemistry of acid mine waters, In: Plumlee, G.S. Logsdon, M.J. (Eds.), The Environmental Geochemistry of Mineral Deposits, Part A Processes, Techniques, and Health Issues, Society of Economic Geologists, Reviews in Economic Geology 6A, pp. 133-156.

Nordstrom, D.K., Alpers, C.N., Ptacek, C.J., Blowes, D.W., 2000. Negative pH and extremely acidic mine waters from Iron Mountain, California. Environ. Sci. Technol. 34, 254-258.

Oliveira, V.M.J., Matos, J.X., Rosa, C., 2001. The NNW sector of the Iberian Pyrite Belt - new exploration perspectives for the next decade. Geode Workshop - Massive Sulphide Deposits in the Iberian Pyrite Belt: New Advances and Comparison with Equivalen Systems, Aracena, Spainpp. 34-37.

Parkhurst, D.L., Appelo, C.A.J., 1999. Users guide to PHREEOC (Version 2) - a computer program for speciation, batch-reaction, one-dimensional transport, and inverse geochemical calculations. Water-Resources Investigation Report 99-4259. U.S Geological Survey, Denver, Colorado.

Piper, A.M., 1944. A graphic procedure in the geochemical interpretation of water analyses. Am. Geophys. Union Trans. 25, 914-923.

Plumlee, G.S., Smith, K.S., Montour, M.R., Ficklin, W.H., Mosier, E.L., 1999. Geologic controls on the composition of natural waters and mine waters draining diverse mineral deposit types. In: Filipek, L.H., Plumlee, G.S. (Eds.), The Environmental Geochemistry of Mineral Deposits, Part B. Case Studies and Research Topics: Society of Economic Geologists, Reviews in Economic Geology 6B, pp. 373-432.

Protano, G., Riccobono, F., 2002. High contents of rare earth elements (REEs) in stream waters of a $\mathrm{Cu}-\mathrm{Pb}-\mathrm{Zn}$ mining area. Environ. Pollut. 117, 499-514.

Ramsey, M.H., Thompson, M., Banerjee, E.K., 1987. Realistic assessment of analytical data quality from inductively coupled plasma atomic emission spectrometry. Anal. Proc. 24, 260-265.

Regenspurg, S., Brand, A., Peiffer, S., 2004. Formation and stability of schwertmannite in acidic mining lakes. Geochim. Cosmochim. Acta 68, 1185-1197.

Reimann, C., de Caritat, P., 1998. Chemical Elements in the Environment - Factsheets for the Geochemist and Environmental Scientist. Springer-Verlag, Berlin (398 pp.).

Reis, A.P., Ferreira da Silva, E., Cardoso Fonseca, E., Patinha, C., Barrosinho, C., Matos, J. 2012. Environmental assessment of the Caveira abandoned mine (Southern Portugal): part 1: characterization of metal contaminated soil. Soil Sediment Contam. 21, 227-254.

Sainz, A., Grande, J.A., dela Torre, M.L., 2003. Odiel River, acid mine drainage and current characterization by means of univariate analysis. Environ. Int. 29, 51-59.

Sánchez-Rodas, D., Gómez-Ariza, J.L., Giráldez, I., Velasco, A., Morales, E., 2005. Arsenic speciation in river and estuarine water from southwest Spain. Sci. Total Environ. $345,207-217$

Singer, P.C., Stumm, W., 1970. Acid mine drainage: the rate-determining step. Science $167,1121-1123$.

SIORMINP, 2002. Sistema de informação de ocorrências e recursos minerais portugueses. Instituto Geológico e Mineiro, Lisboa.

SNIRH-APA - Sistema Nacional de Informação de Recursos Hídricos-Agência Portuguesa do Ambiente, e. Rios de Portugal Continental. http://snirh.pt/junior/?menu=2.1\&item $=8$ (accessed on June 2015).

Sracek, O., Choquette, M., Gélinas, P., Lefebvre, R., Nicholson, R.V., 2004. Geochemica characterization of acid mine drainage from a waste rock pile, Mine Doyon, Québec, Canada. J. Contam. Hydrol. 69, 45-71. 
Strauss, G., 1970. Sobre la geologia de la provincia piritífera del SW de la Península Ibérica y de sus yacimientos, en especial sobre la mina de pirita de Lousal (Portugal). Memorias ITGE T 77, p. 266.

STREAMES Project, t. Stream Reach Management: an expert system. Ribeira de Grândola (Portugal). http://www.pcb.ub.edu/streames/sites/grandola.htm (accessed on June 2015).

U.S. EPA, 1986. Quality Criteria for Water, Office of Water. EPA, Washington, DC, USA (440/5-86-001).

U.S. EPA, 1999. National Recommended Water Quality Criteria - Correction. U.S. Environmental Protection Agency, Washington, DC, USA (EPA-822-Z-99-001).

U.S. EPA, 2002. Water Quality Criteria Recommendation. U.S. Environmental Protection Agency (EPA-822-R-02-047)
Vara, I.P., 1963. Piritas de Huelva, su historia, minería y aprovechamiento. Ed. Summa, Madrid, p. 1003

Williams, D.J., Bigham, J.M., Cravotta, C.A., Traina, S.J., Anderson, J.E., Lyon, J.G., 2002. Assessing mine drainage $\mathrm{pH}$ from the color and spectral reflectance of chemical precipitates. Appl. Geochem. 17, 1273-1286.

Witters, H.E., Van Puymbroeck, S., Stouthart, A.J.H.X., Wendelaar Bonga, S.E., 1996. Physicochemical changes of aluminum in mixing zone: mortality and physiological disturbances in brown trout (Salmo trutta L.). Environ. Toxic Chem. 15, 986-996.

Yu, J., Heo, B., Choi, I., Chang, H., 1999. Apparent solubilities of schwertmannite and ferrihydrite in natural stream waters polluted by mine drainage. Geochim. Cosmochim. Acta 63, 3407-3416. 